\title{
Article \\ Response of Tomato-Pseudomonas Pathosystem to Mild Heat Stress
}

\author{
Loredana Scalschi ${ }^{\dagger}$, Emma Fernández-Crespo ${ }^{\dagger}$, Marcel Pitarch-Marin, Eugenio Llorens $\mathbb{D}$, \\ Ana Isabel González-Hernández $\mathbb{1}$, Gemma Camañes $\mathbb{1}$, Begonya Vicedo $* \mathbb{1}$ and Pilar García-Agustín
}

check for

updates

Citation: Scalschi, L.;

Fernández-Crespo, E.; Pitarch-Marin, M.; Llorens, E.; González-Hernández,

A.I.; Camañes, G.; Vicedo, B.;

García-Agustín, P. Response of

Tomato-Pseudomonas Pathosystem to Mild Heat Stress. Horticulturae 2022, 8, 174. https://doi.org/ 10.3390/horticulturae8020174

Academic Editor: Rinu Kooliyottil

Received: 14 January 2022

Accepted: 18 February 2022

Published: 20 February 2022

Publisher's Note: MDPI stays neutral with regard to jurisdictional claims in published maps and institutional affiliations.

Copyright: () 2022 by the authors Licensee MDPI, Basel, Switzerland. This article is an open access article distributed under the terms and conditions of the Creative Commons Attribution (CC BY) license (https:/ / creativecommons.org/licenses/by/ $4.0 /)$.
Grupo de Bioquímica y Biotecnología, Área de Fisiología Vegetal, Departamento de Ciencias Agrarias y del Medio Natural, ESTCE, Universitat Jaume I, 12071 Castellón, Spain; scalschi@uji.es (L.S.); ecrespo@uji.es (E.F.-C.); al288117@uji.es (M.P.-M.); ellorens@uji.es (E.L.); gonzalan@uji.es (A.I.G.-H.); camanes@uji.es (G.C.); garciap@uji.es (P.G.-A.)

* Correspondence: bvicedo@uji.es

+ These authors contributed equally to this work.
Abstract: Higher plants suffer from mild heat stress when temperatures increase by $5{ }^{\circ} \mathrm{C}$ above optimum growth temperatures. This produces changes at the cellular and metabolic levels, allowing plants to adapt to heat conditions. This study investigated an increase of $5{ }^{\circ} \mathrm{C}$ above the optimum growth temperature $\left(26^{\circ} \mathrm{C}\right)$ of tomato plants in the tomato-Pseudomonas syringae pv. tomato pathosystem. A temperature increase above $26^{\circ} \mathrm{C}$ affects plant development, the defensive pathways activated against Pseudomonas syringae pv. tomato strain DC3000 (PstDC3000), and the bacterial growth and virulence machinery. The results demonstrated that tomato plants were able to acclimate to mild heat stress, showing no symptoms of damage. Moreover, plants subjected to a $5^{\circ} \mathrm{C}$ increase (T31 ${ }^{\circ} \mathrm{C}$ plants) showed higher basal levels of metabolites such as proline and putrescine, which probably act as compatible osmolytes. This demonstrates their importance as key components of thermotolerance. When grown under mild heat stress, plants were less susceptible to PstDC3000 and showed increased accumulation of abscisic acid, jasmonic acid-isoleucine, and spermine. In addition, the temperature increase negatively affected the infectivity of PstDC3000. Inhibition of the genes responsible for quorum sensing establishment and synthesis of flagellin and coronatine was observed in bacteria extracted from $\mathrm{T} 31^{\circ} \mathrm{C}$ plants. Analysis of the genes involved in the synthesis of the type III secretion system indicates the important role of this system in bacterial growth under these conditions. As the known resistance mechanisms involved in the defense against PstDC3000 were not activated, the changes in its virulence mechanisms under high temperatures may explain the lower infection observed in the $\mathrm{T} 31^{\circ} \mathrm{C}$ plants.

Keywords: tomato; Pseudomonas syringae; mild heat stress; virulence systems; COR; T3SS

\section{Introduction}

Increased temperatures resulting from climate change are a significant threat to agriculture and food security [1,2]. Current models predict an increase in the average global temperature of between 2 and $5{ }^{\circ} \mathrm{C}$ over the next hundred years. Extreme weather events (including heat waves) will have devastating consequences for crop productivity [3]. Temperatures of $5{ }^{\circ} \mathrm{C}$ above optimum growth temperature are considered stressful for higher plants, and plants respond by changes at cellular and metabolic levels [4,5]. Certain organs respond to moderate temperature stress by increasing growth rates and proportionally decreasing growth duration [6]. Specific changes in plant organs enhance their ability to survive exposure to high temperatures [7]. Moreover, the activation of heat stress transcription factors and downstream heat shock proteins are key factors in enhanced heat stress tolerance [8,9]. Temperature increases reduce the water content of plant tissues [10]. The synthesis of compounds such as soluble sugars, polyols, proline, and glycine betaine are increased during heat stress to enhance water absorption from the soil and maintain 
plant turgor [11,12]. In addition to acting as compatible osmolytes, these compounds actively participate in the response to temperature stress by increasing protein stability, stabilizing the structure of the membrane bilayer, acting as buffers of redox potential, and preventing oxidative damage [13-15]. The biochemical and physiological responses of plants to abiotic stress related to climate change, such as increased temperature, are well documented. However, little is known about how these environmental factors affect plantpathogen interactions. A susceptible plant host, a virulent pathogen and the appropriate environmental conditions are required for a disease to occur. This is known as the "disease triangle" in plant pathology [16]. Although plants do not have an advanced immune system like animals, they employ sophisticated strategies to counteract colonization by microbial pathogens $[17,18]$. Hormonal responses are key components in plant immunity. Salicylic acid (SA) is part of the defense response against biotrophic pathogens. Jasmonic acid (JA) participates in defense responses against necrotrophs and insects [19-21]. In addition to traditional defensive responses, plant immunity to microbial pathogens is regulated by distinct pathways related to nitrogen compounds such as amino acids and polyamines (PAs), among others [22,23]. Environmental factors can alter defensive responses. These responses include pattern-triggered immunity, effector-triggered immunity, RNA interference, and defense hormone networks. Recent studies have reported on the impact of these responses on the progression of some diseases [24]. Similarly, environmental factors can alter the incidence of disease by directly affecting the virulence factors of pathogens. Deepening of knowledge on how specific environmental factors interfere at both plant and pathogen level would allow for the elaboration of solid strategies to develop crops capable of adapting and surviving increasingly unpredictable climatic conditions. Pseudomonas syringae pv. tomato DC3000 (PstDC3000) is a significant pathogen because it infects economically important crops such as tomatoes and bell peppers. It is also considered a suitable organism for studies of plant-pathogen interactions $[25,26]$. The life cycle of PstDC3000 consists of two stages, namely, an epiphytic stage on the leaf surface followed by an endophytic phase in the leaf apoplast, where it survives as a pathogen [27]. The bacterium uses flagellummediated motility, both as a means to explore leaf surfaces during the epiphytic phase, as well as to enter the leaf apoplast via natural openings, such as stomata or wounds, during the pathogenic phase. PstDC3000 also uses a cell density-dependent regulation system known as quorum sensing (QS), which plays a significant role in both stages of its life cycle. The psyI gene is responsible for the biosynthesis of $\mathrm{N}$-acyl homoserine lactones, which function as QS signals [28]. In addition, PstDC3000 uses two important virulence mechanisms to cause disease, namely, phytotoxin coronatine (COR) and the type III secretion system (T3SS). COR is a toxin that promotes the opening of stomata for bacterial entry and contributes to bacterial growth in the apoplast and the induction of disease symptoms [27]. COR is synthesized from two precursor molecules-polyketide coronafacic acid (CFA) and coronamic acid (CMA; a cyclized isoleucine derivative). CFA and CMA are joined together by the coronafacate ligase $(\mathrm{Cfl})$ enzyme. The T3SS is a complex structure encoded by the hypersensitive response and pathogenicity $(h r p)$ conserved genes [29]. PstDC3000 uses T3SS to inject effector proteins directly into the host cell cytoplasm [30]. PstDC3000 can inject more than 30 effectors into plant cells [31]. Temperature is an important environmental factor that affects PstDC3000 infectivity. Although the optimal temperature for the growth of the bacterium in vitro is approximately $28^{\circ} \mathrm{C}$, there are studies that indicate that even at this temperature, virulence factors can be inhibited. However, most of these studies were carried out in vitro and did not consider that high temperatures may also affect the defensive system of the plant and the virulence of the bacteria. Contradictory results regarding the effect of high temperature on PstDC3000 virulence mechanisms in plants indicate that this aspect must be studied in greater detail [32]. Several recent studies have investigated how agronomic plants and phytopathogenic-associated organisms responded to sudden increases in temperature [24]. However, the way in which sudden temperature rise affects the overall pathosystem still requires further investigation. 
In this study, we investigated the effect of an increase of $5{ }^{\circ} \mathrm{C}$ above the optimum growth temperature on the tomato-PstDC3000 pathosystem, analyzing growth and defensive pathways in the host, as well as how the growth and virulence machinery of the pathogen were affected.

\section{Materials and Methods}

\subsection{Plant Material and Temperature Assay}

Tomato seeds (Solanum lycopersicum Mill 'Ailsa Craig') were germinated in vermiculite in a growth chamber under the following environmental conditions: light/dark cycle of $16 / 8 \mathrm{~h}$, temperature of $26 / 18{ }^{\circ} \mathrm{C}$, light intensity of $200 \mu \mathrm{mol} \mathrm{m}{ }^{-2} \mathrm{~s}^{-1}$, and a relative humidity of $60 \%$. The seeds were irrigated twice a week with distilled water. After two weeks, the plants were separated into two groups and transferred to another culture chamber. The control plants $\left(\mathrm{T} 26^{\circ} \mathrm{C}\right.$ ) were kept at temperatures of $26^{\circ} \mathrm{C}$ and $18{ }^{\circ} \mathrm{C}$ (day and night, respectively), and the plants in the test group $\left(\mathrm{T} 31^{\circ} \mathrm{C}\right)$ were grown for two weeks at temperatures of $31^{\circ} \mathrm{C}$ and $23^{\circ} \mathrm{C}$ (day and night, respectively). Seedlings of both groups were irrigated twice a week with Hoagland solution, applied at the same proportion.

\subsection{Biomass and Chlorophyll Content}

Four-week-old tomato plants (sample group $\mathrm{T} 26^{\circ} \mathrm{C}$ and $\mathrm{T} 31^{\circ} \mathrm{C}$ ) were collected and dried in an oven for $2 \mathrm{~d}$ at $65^{\circ} \mathrm{C}$. Dried plant tissues were weighed, and the dry weight (DW) of 10 plants was obtained and expressed as biomass. The chlorophyll levels in the leaves of 4-week-old tomato plants were measured using a chlorophyll meter (SPAD; Minolta, Tokyo, Japan).

\subsection{P. syringae Bioassay}

P. syringae pv. tomato DC3000 plants were grown at $28{ }^{\circ} \mathrm{C}$ in the $\mathrm{KB}$ medium [33]. Rifampicin (Sigma-Aldrich) was added to the KB medium at $50 \mu \mathrm{g} \mathrm{ml}^{-1}$. Bacterial suspensions were measured in the spectrophotometer to prepare the inoculation solution consisting of $5 \times 10^{5}$ colony-forming units ( $\mathrm{cfu} / \mathrm{mL}$ dissolved in sterile MgSO4 (10 mM) (Scharlab) containing 0.01\% of the surfactant Silwet L-77 (Osi Specialties, Danbury, CT, USA). Four-week-old tomato plants were infected by dipping the third and fourth leaves into the bacterial suspension. The disease rate was measured $72 \mathrm{~h}$ post-inoculation (hpi) by determining the percentage of the leaf surface covered by dark brown spots. Samples were collected $48 \mathrm{hpi}$ for molecular and hormonal analyses. For each treatment, at least three samples were collected for colony counting (cfu/g), and 20 samples were collected for measuring of the rate of the disease [25]. Each experiment was conducted in independent triplicates.

\subsection{Chromatographic Analysis}

For amino acid, polyamine, and hormone quantification, tomato leaves were collected at $48 \mathrm{hpi}$, frozen in liquid nitrogen, ground, and stored at $-80^{\circ} \mathrm{C}$. For amino acid analysis, dry tissue $(0.1 \mathrm{~g})$ was homogenized with $800 \mu \mathrm{L}$ of extraction solution. The extraction solution consisted of $400 \mu \mathrm{L}$ of distilled water, $200 \mu \mathrm{L}$ of chloroform, and $200 \mu \mathrm{L}$ of methanol per sample. Internal standards (100 ng of Phe ${ }^{13} \mathrm{C}_{9}{ }^{15} \mathrm{~N}$ and $100 \mathrm{ng}$ of $\mathrm{Thr}{ }^{13} \mathrm{C}_{4}{ }^{15} \mathrm{~N}$ ) were added prior to extraction [34]. Dry tissue (0.05 g) was homogenized in ultrapure water $(2.5 \mathrm{~mL})$ for hormonal analysis, and $100 \mathrm{ng} \mathrm{mL}^{-1}$ of a mixture of internal standards $\left(d^{6}\right.$ ABA, $d^{4}$-SA and dihydrojasmonic acid) was added prior to extraction [34]. For polyamine quantification, dry tissue $(0.025 \mathrm{~g})$ was homogenized in $2 \%$ TCA, and a mixture of internal standards containing $\left[{ }^{13} \mathrm{C}_{4}\right]$ putrescine and 1,7-diamineheptane was added to each sample [35]. Chromatographic specifications for amino acids, hormones, and PAs are described in each reference. 


\subsection{Gene Expression}

Gene expression by qRT-PCR was performed on the RNA samples extracted from leaves using the Total Quick RNA Cells and Tissues kit (Omega Bio-tek, Norcross, GA, USA), according to the manufacturer's instructions. The tomato leaf samples for RNA isolation were collected at $48 \mathrm{hpi}$. The RT reaction was performed with pure RNA, according to the manufacturer's instructions for the Omniscript Reverse Transcriptase kit (QIAGEN, Hilden, Germany). The primers used for the qRT-PCR are listed in Table 1. EF1 $\alpha$ gene expression level was used as an internal housekeeping control. At least three independent experiments were performed to confirm the results.

Table 1. Primers used for plant gene expression analyses.

\begin{tabular}{|c|c|c|}
\hline Function & Gene & Primer \\
\hline Pathogenesis-related protein 1 & PR1 & $\begin{array}{c}\text { F 5'-CCGTGCAATTGTGGGTGTC-3' } \\
\text { R 5'-GAGTTGCGCCAGACTACTTGAGT-3' }\end{array}$ \\
\hline Arginine decarboxylase & $A D C$ & $\begin{array}{l}\text { F 5'-GGGCTTGGAATCGACTATGA-3' } \\
\text { R 5'-CCCGGTTTCAAAAATCAGAA-3' }\end{array}$ \\
\hline Spermidine synthase & SPDS & $\begin{array}{l}\text { F 5'-GGTGACGGAGTTGCATTTTT-3' } \\
\text { R 5'-GCGGCAATTAGCAACAATTT-3' }\end{array}$ \\
\hline Elongation factor 1-alpha & $E F 1 \alpha$ & $\begin{array}{c}\text { F 5'-GACAGGCGTTCAGGTAAGGA-3' } \\
\text { F 5'-GGGTATTCAGCAAAGGTCTC-3 }\end{array}$ \\
\hline
\end{tabular}

To extract bacterial RNA from infected plants, we employed the protocol described by Yu et al. [36] for extracting RNA from apoplastic PstDC3000 recovered from infected leaves. PstDC3000 grown on KB agar plates for $48 \mathrm{~h}$ at $26{ }^{\circ} \mathrm{C}$ or $31^{\circ} \mathrm{C}$ was used for RNA isolation from bacteria cultured in vitro. Bacterial cell suspensions $\left(1 \times 10^{5}\right)$ were incubated with shaking in liquid $\mathrm{KB}$ medium at $26^{\circ} \mathrm{C}$ or $31^{\circ} \mathrm{C}$, for 6 and $48 \mathrm{~h}$ before RNA extraction. RNA extraction was performed as described by Scalschi et al. [37]. Reverse transcription was performed as described by Scalschi et al. [34]. Quantitative polymerase chain reaction (PCR) was conducted using the StepOne ${ }^{\mathrm{TM}}$ Real-Time PCR System (Thermo Fisher Scientific, Waltham, MA, USA). The primers used for the assays are listed in Table 2. The recA gene was used as the internal reference.

Table 2. Primers used for bacterial gene expression analyses.

\begin{tabular}{|c|c|c|}
\hline Function & Gene & Primer \\
\hline \multirow[t]{3}{*}{ Coronatine synthesis } & $c f a 1$ & $\begin{array}{c}\text { F 5'-AAAACCATCGTCGACATTCTG-3' } \\
\text { R 5'-GTTGGCGTTGAGGTCGATA-3' }\end{array}$ \\
\hline & $c m a B$ & $\begin{array}{l}\text { F 5'-AATTCGACACCCGACAAGAC-3' } \\
\text { R 5'-ACTAGGGGCTTCAGGTCCAT-3' }\end{array}$ \\
\hline & $c f l$ & $\begin{array}{l}\text { F 5'-ACAGCTGAAGCAGCACTTGA-3' } \\
\text { R 5'-CGAGGATCTCTCGGTAGTCG-3' }\end{array}$ \\
\hline \multirow[t]{3}{*}{$\begin{array}{l}\text { Type III secretion system, type III } \\
\text { secretion system-associated pilus, } \\
\text { and effector synthesis }\end{array}$} & $h r p L$ & $\begin{array}{l}\text { F 5'-TCTCCAGTGCGTGTTTCTTG-3' } \\
\text { R 5'-AGCTTTCCTGATACGGCTGA-3 }{ }^{\prime}\end{array}$ \\
\hline & hrpA & $\begin{array}{l}\text { F 5'-CCTCCAAACTCACCAACCTT-3' } \\
\text { R 5'-CGGACTCTTTACTGGCCTTG-3' }\end{array}$ \\
\hline & avrPtoB & $\begin{array}{l}\text { F 5'-ACCCTATCGCGTCACAATTC-3' } \\
\text { R 5'-CATGAACGCCAGGTCCTTAT-3 }{ }^{\prime}\end{array}$ \\
\hline Quorum sensing establishment & psyI & $\begin{array}{l}\text { F 5'-GGCTTGAATGGAATGTTCGT-3' } \\
\text { R 5'-CAGGTGTTGATCAGCCGTAA-3' }\end{array}$ \\
\hline Flagellin synthesis & fliC & $\begin{array}{l}\text { F 5'-ATCTGAACGGCAAGAACCTG-3' } \\
\text { R 5'-TGCGCTCAAAGTCAGAGAGA-3' }\end{array}$ \\
\hline Internal reference & $\operatorname{rec} A$ & $\begin{array}{l}\text { F 5'-CGGCAAGGGTATCTACCTCA-3' } \\
\text { R 5'-CTTTGCAGATTTCCGGGTTA-3' }\end{array}$ \\
\hline
\end{tabular}




\subsection{Bacterial Acclimation Assays}

PstDC3000 was grown on $\mathrm{KB}$ plates at $26^{\circ} \mathrm{C}$ and $31^{\circ} \mathrm{C}$ and sub-cultured nine times to check the ability to adapt to high temperatures. Both bacteria grown at $26{ }^{\circ} \mathrm{C}$ and $31{ }^{\circ} \mathrm{C}$ were sub-cultured every 3 days in solid $\mathrm{KB}$ medium. The growth rate in the liquid $\mathrm{KB}$ was recorded each week. The growth assay was performed in a total volume of $200 \mu \mathrm{L}$ microtiter wells, using an initial bacterial concentration of $1 \times 10^{5} \mathrm{cfu} / \mathrm{mL}$. The microtiter plates were incubated with shaking at $26^{\circ} \mathrm{C}$ or $31^{\circ} \mathrm{C}$ for $96 \mathrm{~h}$. The optical density was determined at $0,24,48,72$, and 96 post-inoculation in a microplate reader (MB-580, Heales). Twenty independent replicates were measured at each time point.

\subsection{Bacterial Mutants Growth Assay}

We tested the effect of temperature on PstDC3000 and several mutants. The mutants used were those defective in COR synthesis $(\Delta c m a-c f a)$, in T3SS synthesis and assembly $(\triangle h r p L)$, in pillus formation $(\triangle h r p A)$, and in effector synthesis ( $\triangle a v r P t o-\triangle a v r P t o B)$. The growth assay was performed as described in bacterial acclimation assays. The microtiter plates were incubated with shaking at $26^{\circ} \mathrm{C}$ or $31^{\circ} \mathrm{C}$ for $24 \mathrm{~h}$, and the optical density was determined at $600 \mathrm{~nm}$. Twelve independent replicates were performed for each strain and temperature.

\subsection{Swimming Assays}

P. syringae inoculum was obtained as described above and used to analyze the effect of temperature increases on the mobility of the bacteria in vitro. Five microliters of the bacterial suspension grown either at $28{ }^{\circ} \mathrm{C}$ or $31^{\circ} \mathrm{C}$ were inoculated with a sterile pipette tip on $\mathrm{KB}$ agar plates containing $50 \% \mathrm{~KB}$ and $0.25 \%$ agar. The plates were incubated at $26{ }^{\circ} \mathrm{C}$ or $31{ }^{\circ} \mathrm{C}$ for $96 \mathrm{~h}$. The diameter of the culture was measured at $24 \mathrm{~h}$ and $96 \mathrm{~h}$ after incubation started. Five plates were used for each temperature condition.

\subsection{Statistical Analysis}

Statistical analysis was performed using one-way analysis of variance in the Statgraphics Centurion XVI software of Windows (Statistical Graphics Corp., Rockville, MD, USA). The means were expressed with standard errors and compared using Fisher's least significant difference test at the $95 \%$ confidence intervals. Ten plants were used for each condition in at least three biological replicates. For the in vitro studies of the bacteria, eight replicates were performed in each of the three biological replicates.

\section{Results}

\subsection{Effect of Moderate Temperature Stress on the Growth of Tomato Plants}

Control plants $\left(\mathrm{T} 26{ }^{\circ} \mathrm{C}\right)$ were grown for four weeks at optimum temperatures of $26{ }^{\circ} \mathrm{C}$ and $18{ }^{\circ} \mathrm{C}$ for day and night conditions, respectively. Test plants $\left(\mathrm{T} 31^{\circ} \mathrm{C}\right)$ were grown for two weeks at these temperatures. Then, test plants were transferred to a different culture chamber and subjected to mild-temperature stress, with the temperature increased by $5{ }^{\circ} \mathrm{C}$ to $31^{\circ} \mathrm{C}$ and $23^{\circ} \mathrm{C}$ (day and night, respectively) for two weeks.

Phenotypically, the $\mathrm{T} 31^{\circ} \mathrm{C}$ plants did not display any symptoms of damage on the leaves (data not shown). However, changes in morphology were observed when compared with the $\mathrm{T} 26^{\circ} \mathrm{C}$ plants.

The influence of mild heat stress on plant growth was analyzed, and we observed that $\mathrm{T} 31^{\circ} \mathrm{C}$ plants displayed a statistically significant increase of $37.5 \%$ of total biomass compared with control plants. Moreover, the T31 ${ }^{\circ} \mathrm{C}$ plants developed a darker green color, and their chlorophyll content was $19.58 \%$ higher than that in $\mathrm{T} 26{ }^{\circ} \mathrm{C}$ plants (Figure 1 ). 


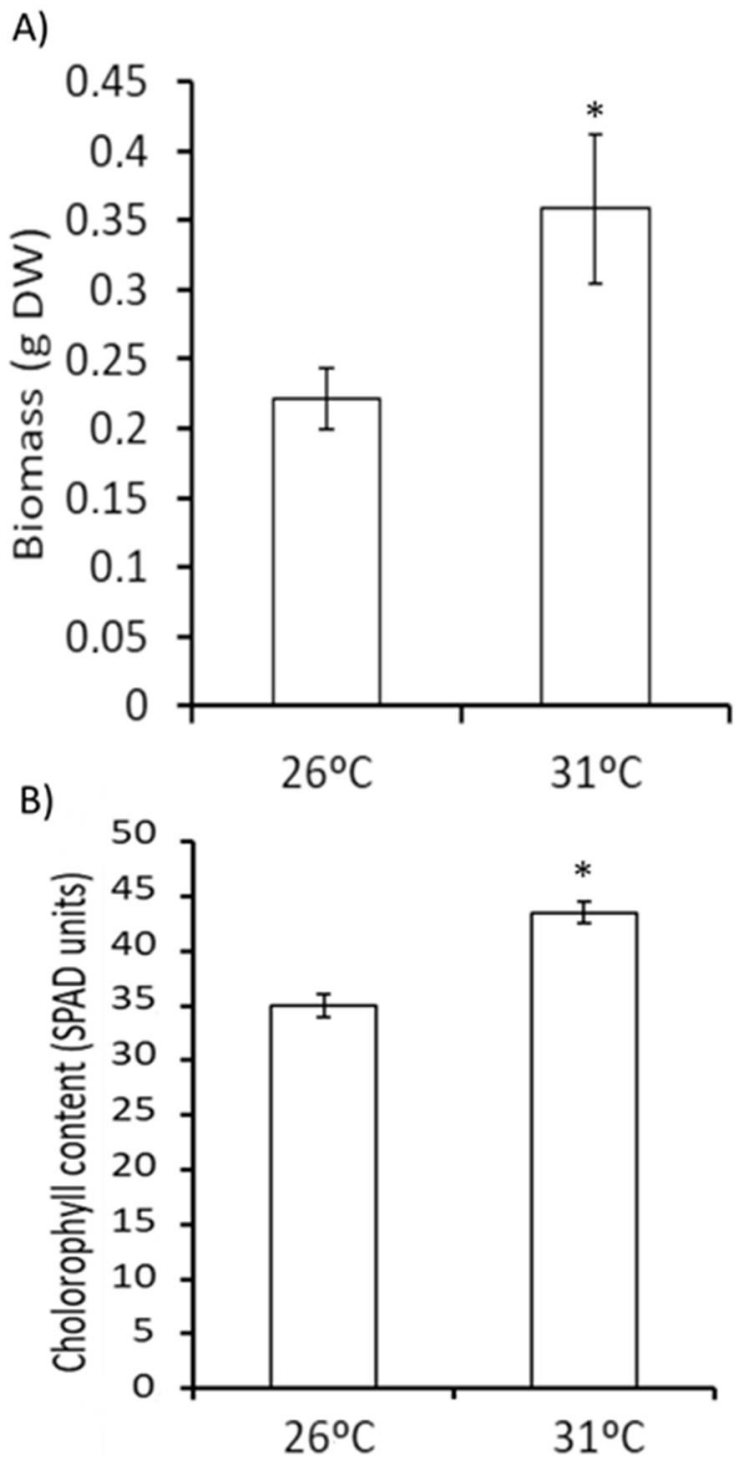

Figure 1. Effect of mild heat stress on growth and chlorophyll content. Four-week-old tomato plants were grown over four weeks at optimum temperatures of $26^{\circ} \mathrm{C}$ and $18{ }^{\circ} \mathrm{C}$ under day and night conditions, respectively. Control plants $\left(\mathrm{T} 26^{\circ} \mathrm{C}\right)$ and test plants $\left(\mathrm{T} 31^{\circ} \mathrm{C}\right)$ were grown for two weeks at $26^{\circ} \mathrm{C}$ and $18{ }^{\circ} \mathrm{C}$ (day and night, respectively) and the test plants were then transferred to another culture chamber to apply the mild-temperature stress by increasing the temperature by $5{ }^{\circ} \mathrm{C}$. (A) Biomass production and (B) chlorophyll content were evaluated. Data show the average of three independent experiments with a pool of 10 plants per experiment \pm SE. Asterisks indicate statistically significant differences $(p<0.05)$.

\subsection{Changes in the Amino Acid Profile as a Result of Mild Heat Stress}

The effect of a moderate temperature increase on the amino acid profile was studied. $\mathrm{T} 31^{\circ} \mathrm{C}$ plants showed no changes in major amino acid (asparagine and glutamine) content compared with control plants. However, these plants showed significant accumulation of some minor amino acids, such as proline, serine, and valine (Table 3). Specifically, T31 ${ }^{\circ} \mathrm{C}$ plants displayed an increase of $70 \%$ and $63 \%$ in proline and serine content, respectively. 
Table 3. Effect of moderate heat stress on amino acid content in tomato plants. Data show the average of three independent experiments of a pool of 10 plants per experiment \pm SE. Asterisk indicates statistically significant differences ( $p<0.05$; LSD test).

\begin{tabular}{|c|c|c|c|c|c|}
\hline & & & $26^{\circ} \mathrm{C}$ (ng/g FW) & $31^{\circ} \mathrm{C}$ (ng/g FW) & \\
\hline \multirow{2}{*}{\multicolumn{2}{|c|}{$\begin{array}{l}\text { Major amino } \\
\text { acids }\end{array}$}} & ASN & $7278.02 \pm 1711.20$ & $7251.85 \pm 3026.76$ & \\
\hline & & GLU & $26,255.48 \pm 5657.45$ & $30,944.55 \pm 4721.04$ & \\
\hline \multirow{14}{*}{$\begin{array}{l}\text { Minor amino } \\
\text { acids }\end{array}$} & \multirow{4}{*}{ From shikimate } & TRP & $659.30 \pm 2.07$ & $691.99 \pm 24.77$ & \\
\hline & & Metil-TRP & $750.31 \pm 18.34$ & $738.04 \pm 23.40$ & \\
\hline & & PHE & $1429.29 \pm 12.45$ & $1487.42 \pm 56.38$ & \\
\hline & & TYR & $555.24 \pm 112.50$ & $484.78 \pm 59.78$ & \\
\hline & Branched chain & VAL & $498.15 \pm 69.06$ & $777.08 \pm 67.92$ & * \\
\hline & \multirow{4}{*}{ From aspartate } & THR & $2265.65 \pm 84.96$ & $2894.86 \pm 772.17$ & \\
\hline & & MET & $240.70 \pm 48.96$ & $198.70 \pm 18.22$ & \\
\hline & & LYS & $37,144.92 \pm 2827.00$ & $41,975.57 \pm 1613.30$ & \\
\hline & & Pip & $173,912.30 \pm 20,894.94$ & $231,928.91 \pm 19,346.29$ & \\
\hline & \multirow{5}{*}{ From glutamate } & HIS & $929.24 \pm 28.03$ & $937.74 \pm 59.81$ & \\
\hline & & PRO & $15,879.56 \pm 3711.11$ & $52,493.88 \pm 6191.67$ & * \\
\hline & & SER & $13,013.59 \pm 1553.86$ & $35,274.43 \pm 6943.60$ & * \\
\hline & & ALA & $20,360.30 \pm 4401.66$ & $23,096 \pm 5773.60$ & \\
\hline & & GLY & $54,403.19 \pm 3750.53$ & $56,181.24 \pm 3048.50$ & \\
\hline
\end{tabular}

\subsection{Effect of Mild Heat Stress on a Tomato-PstDC3000 Pathosystem}

We investigated the interaction between the virulent hemi-biotrophic bacteria PstDC 3000 and tomato plants $\left(\mathrm{T} 26^{\circ} \mathrm{C}\right.$ and $\left.\mathrm{T} 31^{\circ} \mathrm{C}\right)$. The study simulated the natural conditions of a climate change scenario, wherein both the plant and the pathogen were subject to temperature stress. $\mathrm{T} 26^{\circ} \mathrm{C}$ plants were inoculated with PstDC3000, which was also grown at $26{ }^{\circ} \mathrm{C}$, while $\mathrm{T} 31^{\circ} \mathrm{C}$ plants were inoculated with bacteria also grown at $31{ }^{\circ} \mathrm{C}$. There was a statistically significant reduction in disease symptoms and in the size of the bacterial population 72 hpi in plants grown under mild temperature stress conditions (Figure 2).

We next investigated how a temperature increase reduced disease severity from PstDC3000. Firstly, we investigated the effect of moderate heat stress on the different defensive pathways of tomato plant against PstDC3000, and secondly, we studied the effect of this stress on the virulence of PstDC3000.

\subsection{Changes in the Hormonal Response against PstDC3000 from Increased Temperatures}

The hormonal profile and marker genes were analyzed simultaneously in $\mathrm{T} 26^{\circ} \mathrm{C}$ and T31 ${ }^{\circ} \mathrm{C}$ plants at $48 \mathrm{hpi}$. There were no significant changes in hormonal levels in plants adapted to moderate heat stress in the absence of PstDC 3000 . However, $\mathrm{T} 31{ }^{\circ} \mathrm{C}$ plants displayed an increase in abscisic acid (ABA) content when compared with the control conditions after infection with PstDC3000 (Figure 3a). These plants also showed significant reduction in SA levels. This correlates with a strong reduction in PR1 expression when compared with $\mathrm{T} 26^{\circ} \mathrm{C}$ plants (Figure $3 \mathrm{~b}, \mathrm{c}$ ). $\mathrm{T} 26^{\circ} \mathrm{C}$ plants displayed an increase in 12oxo-phytodienoic acid (OPDA) and JA content in the oxylipin pathways after PstDC3000 infection (Figure $3 \mathrm{~d}, \mathrm{e}$ ). No OPDA increase was observed in $\mathrm{T} 31^{\circ} \mathrm{C}$-infected plants; however, these plants accumulated JA and JA-isoleucine (JA-Ile) at 48 hpi (Figure 3d,f). 
A)

PstDC3000

Visual score

B)

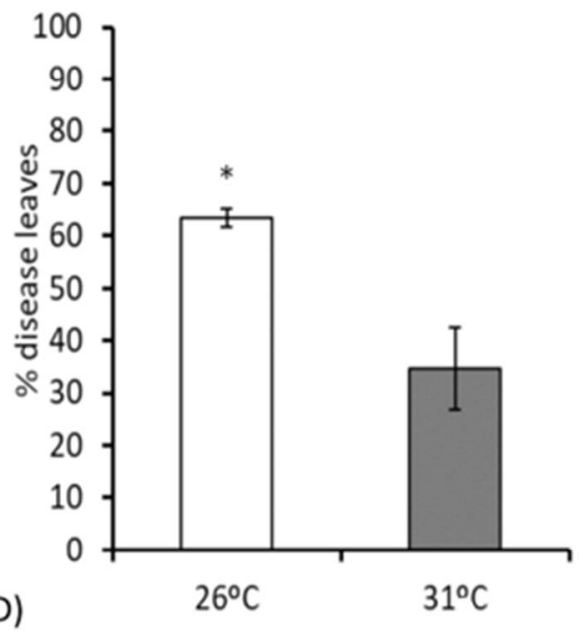

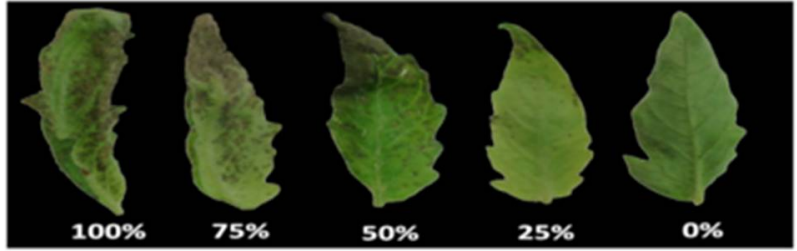

C)
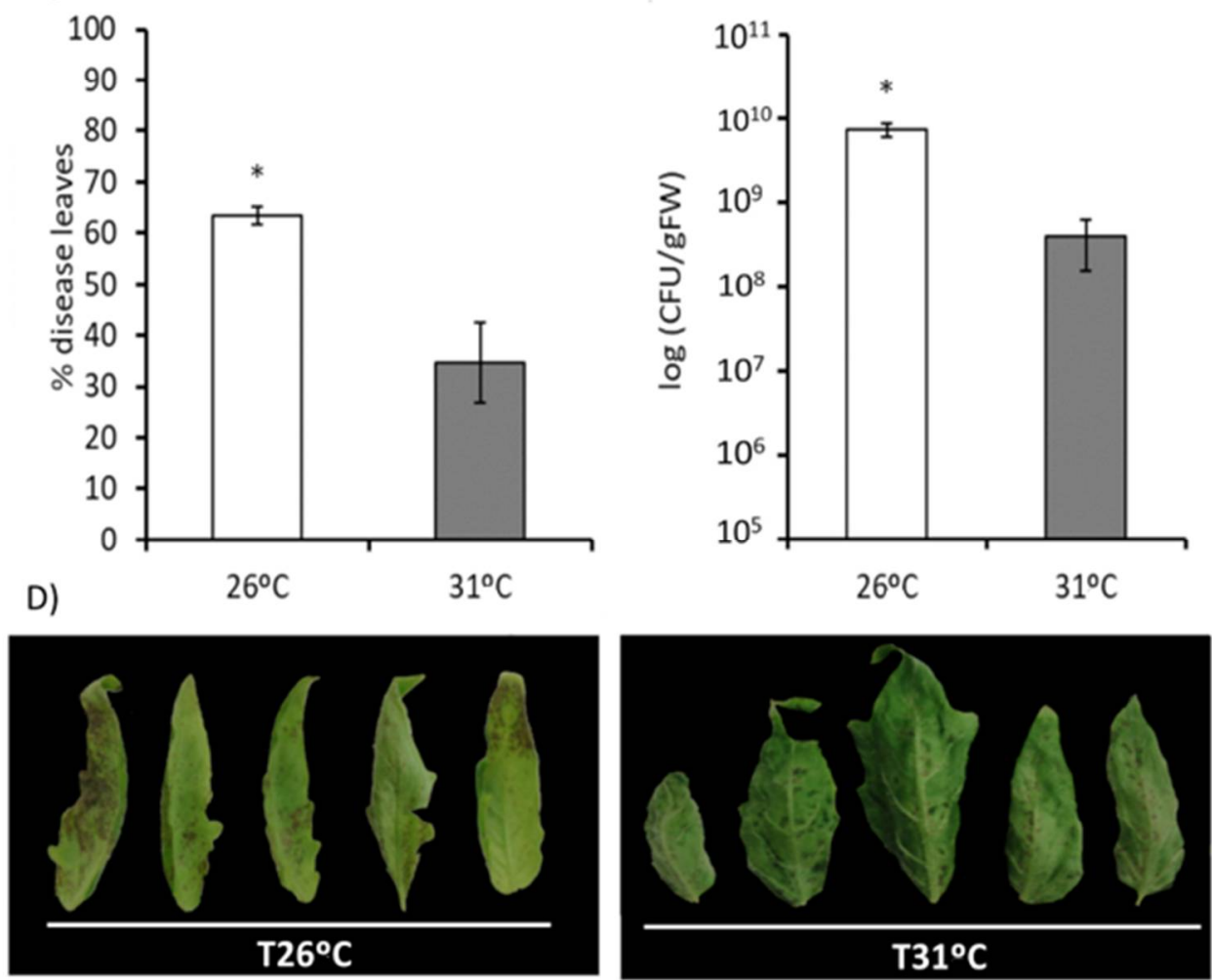

Figure 2. The effect of mild temperature stress on a tomato-PstDC3000 pathosystem. Four-week-old tomato plants grown at $\mathrm{T} 26{ }^{\circ} \mathrm{C}$ and $\mathrm{T} 31^{\circ} \mathrm{C}$ were inoculated with PstDC3000. This was performed by dipping the leaves in a bacterial suspension at $5 \times 10^{5}$ c.f.u. $\mathrm{mL}^{-1}$. Diseased leaves were determined 72 hpi using the visual damage score shown in the photograph (A). Infection levels were measured as a percentage of the infected leaf surface in relation to the total number of analyzed leaves (B) and by recounting of bacterial populations by plating in agar-KB medium $72 \mathrm{hpi}(\mathrm{C})$. The photograph shows a representative picture of disease symptoms under different temperature scenarios (D). Data show the average of three independent experiments, with a pool of 10 plants per experiment $\pm \mathrm{SE}$. An asterisk indicates statistically significant differences ( $p<0.05$; LSD test). 

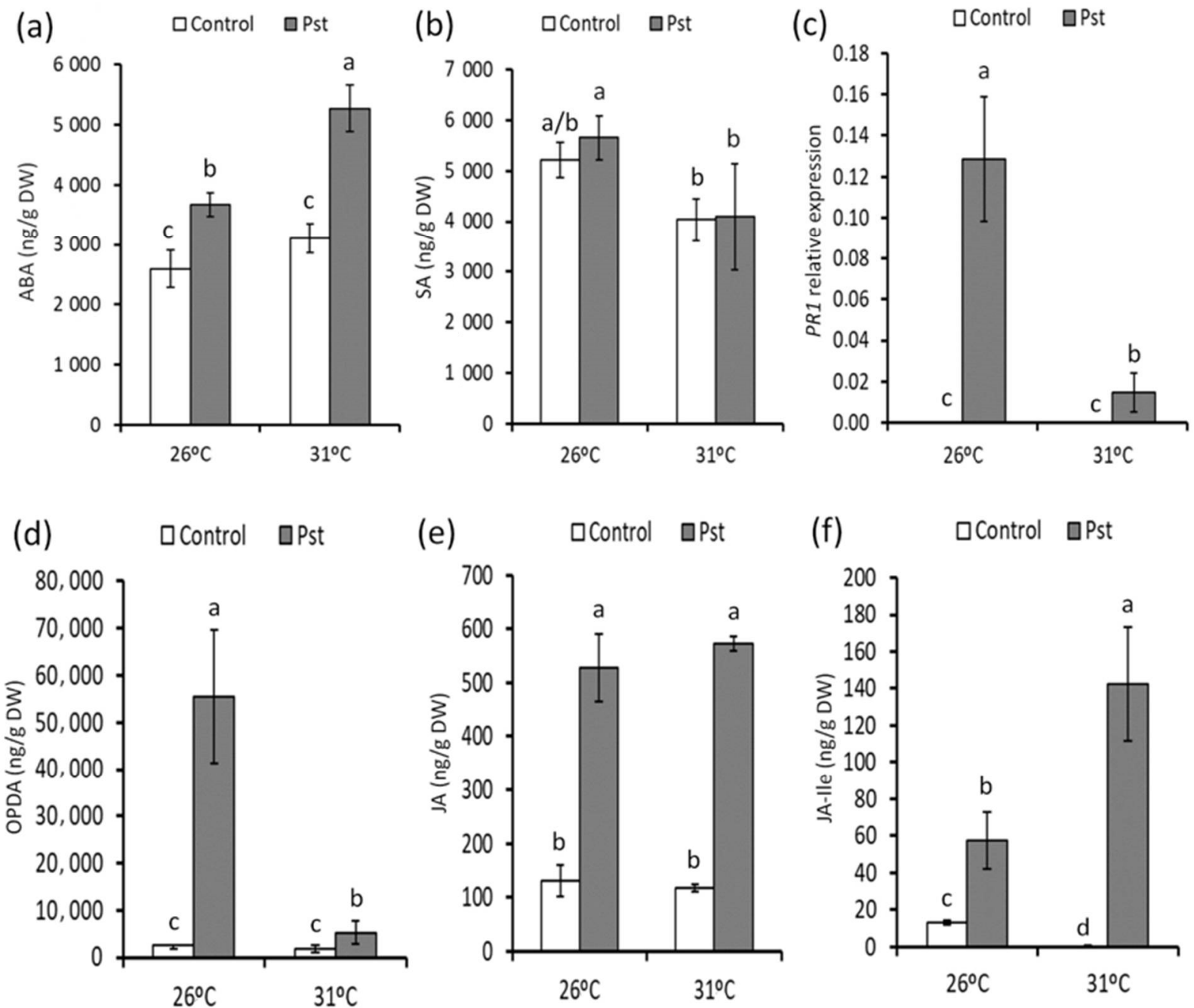

Figure 3. The effect of moderate heat stress on hormonal tomato responses against PstDC 3000 infection. Tomato plants were grown and inoculated as described in Figure 2. Leaves were collected at $48 \mathrm{hpi}$, and ABA (a), SA (b), OPDA (d), JA (e), and JA-Ile (f) levels were determined using UPLCMS. The relative levels of PR1 (c) were analyzed and normalized to the EF1 $\alpha$ gene expression level measured in the same sample. Data show the average of three independent experiments in a pool of 20 plants per experiment \pm SE. Letters indicate statistically significant differences $(p<0.05$; LSD test).

\subsection{Changes in PA Accumulation in Healthy and Infected Plants from Mild Heat Stress}

The effect of moderate heat stress on the polyamines biosynthetic pathways in $\mathrm{T} 26{ }^{\circ} \mathrm{C}$ and $\mathrm{T} 31^{\circ} \mathrm{C}$ plants was analyzed. We observed an induction of arginine decarboxylase $(A D C)$ gene expression, which correlates with a significant accumulation of putrescine in $\mathrm{T} 31{ }^{\circ} \mathrm{C}$ tomato leaves, in the absence of PstDC 3000 infection (Figure $4 \mathrm{a}, \mathrm{c}$ ). $\mathrm{T} 26{ }^{\circ} \mathrm{C}$ and $\mathrm{T} 31^{\circ} \mathrm{C}$ plants displayed an induction of $A D C$ gene expression in response to PstDC3000 infection. Moreover, putrescine accumulation in leaves increased at $48 \mathrm{hpi}$ in both conditions, and this accumulation was more pronounced in control plants (Figure $4 \mathrm{a}, \mathrm{c}$ ). We also observed an induction of the spermidine synthase gene in $\mathrm{T} 26^{\circ} \mathrm{C}$ - and $\mathrm{T} 31^{\circ} \mathrm{C}$-infected plants at $48 \mathrm{hpi}$, as well as accumulation of spermidine, which was more concentrated in $\mathrm{T} 31^{\circ} \mathrm{C}$ plants (Figure $4 b, d$ ). 


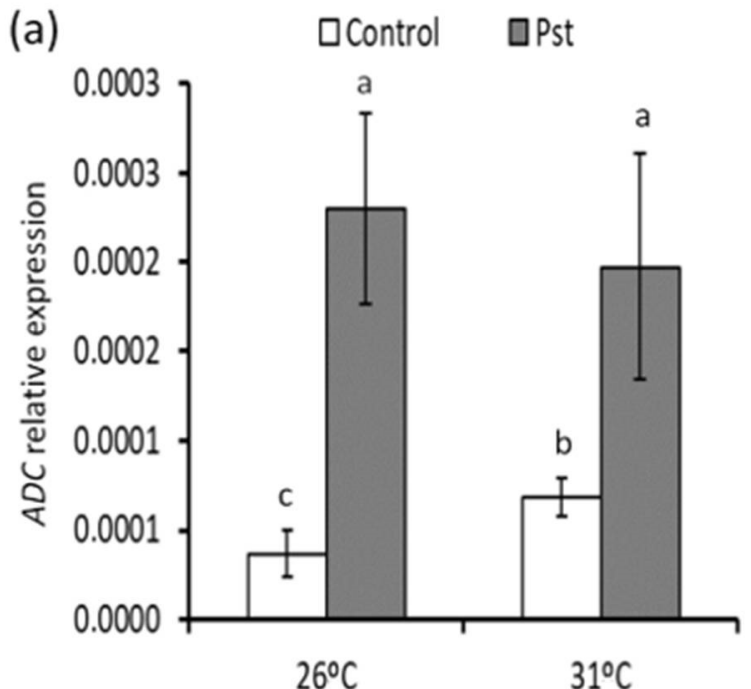

(b)

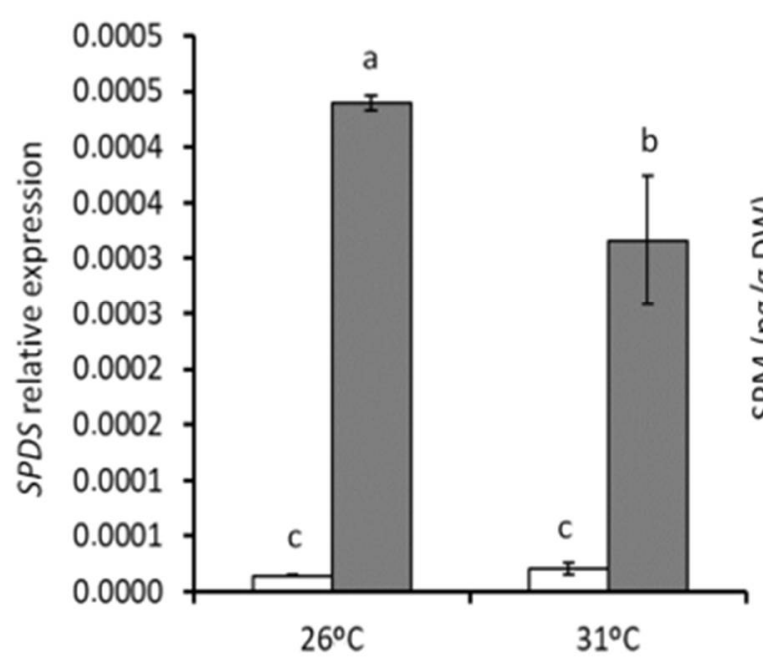

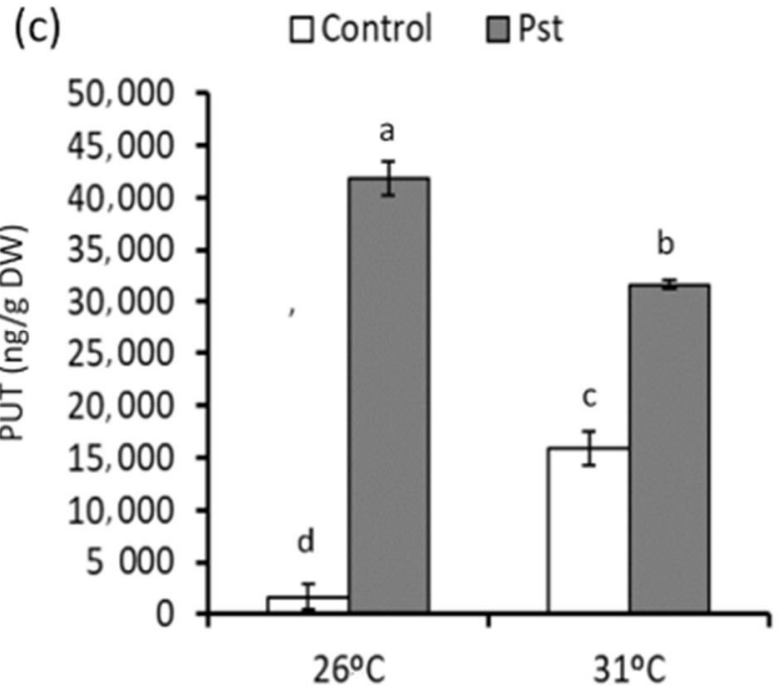

(d)

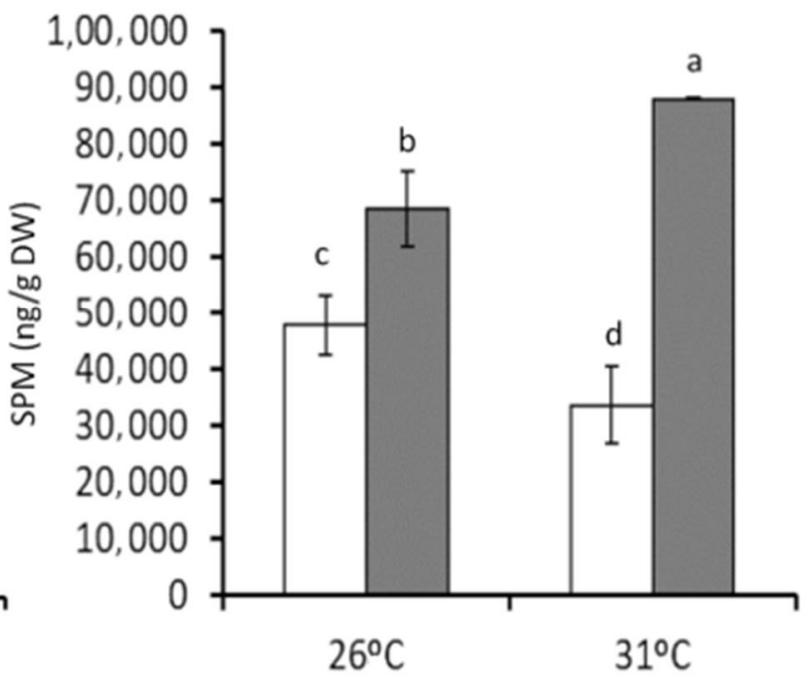

Figure 4. Impact of moderate temperature stress on PA biosynthesis in tomato plants. The expression levels of genes (a) arginine decarboxylase $(A D C)$ and (b) spermidine synthase (SPDS) were analyzed. Moreover, putrescine (PUT) (c) and spermine (SPM) (d) levels were determined in freeze-dried material using UPLC-MS. Data show the average of three independent experiments of a pool of 10 plants per experiment \pm SE. Letters indicate statistically significant differences ( $p<0.05$; LSD test).

\subsection{Effect of Mild Heat Stress on the Virulence of Pseudomonas in Plants}

We also studied the behavior of bacteria in $\mathrm{T} 26{ }^{\circ} \mathrm{C}$ - and $\mathrm{T} 31^{\circ} \mathrm{C}$-inoculated plants. Bacteria were extracted from these plants at $72 \mathrm{hpi}$, and the expression of the following genes was analyzed: the psyI gene responsible for the synthesis of the QS signal molecule; the fliC gene, which encodes flagellin, $c f a, c m a B$, and $c f l$, involved in the synthesis of COR; and the HrpL and HrpA genes, which are involved in the synthesis of the T3SS and in pillus formation, as well as the gene encoding the synthesis of the AvrPtoB effector. The results showed that the expression of the psyI gene was three times lower in the bacteria extracted from the plants subjected to $31^{\circ} \mathrm{C}$, which could hinder the arrival of these bacteria to QS (Figure 5a). In contrast, the results showed a clear inhibition of the expression of the gene involved in flagellin synthesis $(\mathrm{fliC})$ at high temperatures (Figure $5 b$ ). 
(a)

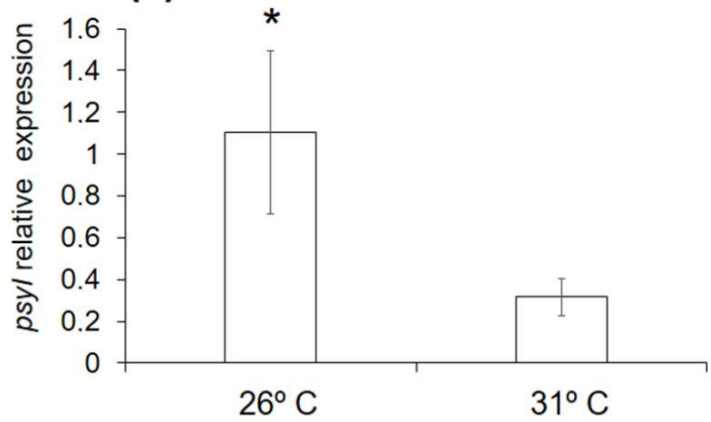

(b)

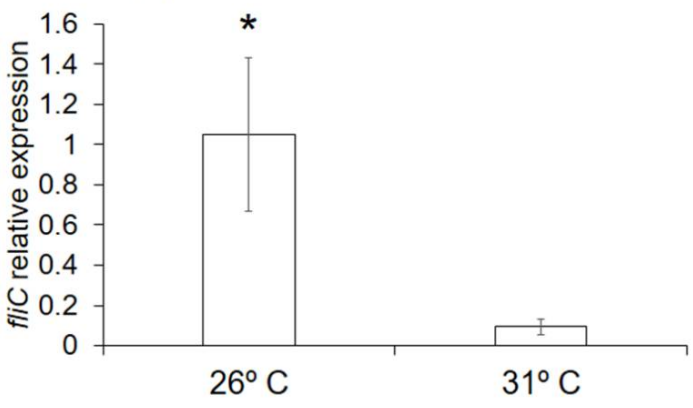

Figure 5. The expression of genes involved in QS establishment and in flagellin synthesis of PstDC3000 were affected by high temperatures in plants. The relative expression of psyI (a) and fliC (b) was determined by qRT-PCR in PstDC3000 extracted from plants grown at $26^{\circ} \mathrm{C}$ or $31^{\circ} \mathrm{C}$. The relative expression levels of $p s y I$ and fliC were normalized to those of $r e c A$. The results represent the means \pm SE from three different experiments. An asterisk indicates statistically significant differences $(p<0.05)$.

In addition, a clear decrease in the expression of all the genes involved in the synthesis of COR was observed, which could also explain the decrease in the infective capacity of the bacteria extracted from plants subjected to $31^{\circ} \mathrm{C}$ (Figure 6a-c). However, it seems that the synthesis of the T3SS and pillus formation was not altered at high temperatures (Figure 6d,e), although a lower expression of the gene involved in the synthesis of the effector AvrPtoB was observed (Figure 6f).
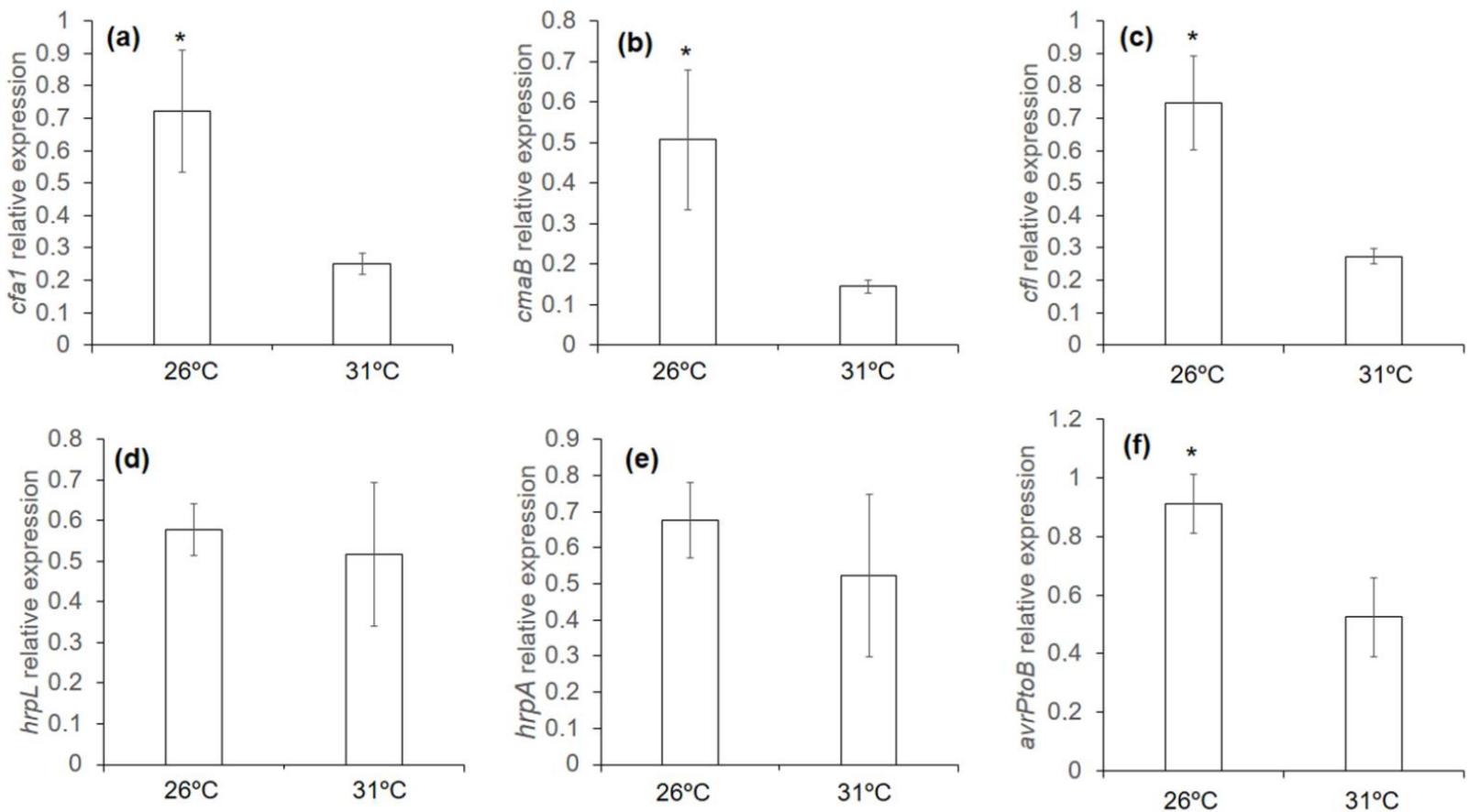

Figure 6. The effect of high temperatures on PstDC3000 virulence genes in plants. The relative expression level of COR synthesis-related genes ((a) $c f a 1$, (b) $c m a B$, and (c) $c f l$ ), of alternative sigma factor for the expressions of the T3SS related genes and the gene encoding the major structural unit of type III secretion system-associated pilus ((d) HrpL and (e) $h r p A$, respectively) and the gene responsible for effector synthesis ((f) avrPtoB) were determined at $72 \mathrm{hpi}$ in bacteria extracted from plants grown at $26^{\circ} \mathrm{C}$ and $31^{\circ} \mathrm{C}$. The rec $A$ gene was used as an endogenous reference gene. The results represent the means $\pm \mathrm{SE}$ from three different experiments. An asterisk indicates statistically significant differences $(p<0.05)$. 


\subsection{Response of Pseudomonas to Mild Temperatures In Vitro}

An in vitro study was undertaken to determine if temperature conditions also affected the bacteria. PstDC3000 had a significantly lower growth in King's B (KB) medium at $31{ }^{\circ} \mathrm{C}$, delaying entry into the exponential phase (Figure 7). The bacteria were not able to adapt to high temperatures, maintaining the difference in growth rate during nine generations.

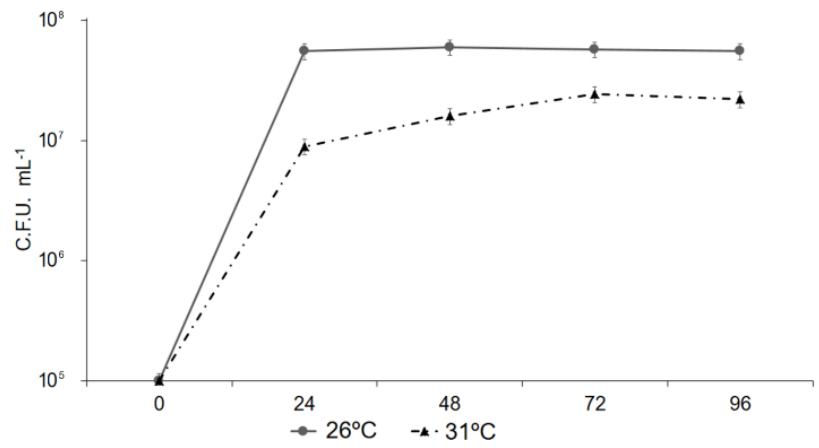

Figure 7. High temperatures affect PstDC3000 growth in vitro. Bacterial growth was performed as described in bacterial acclimation assays. The results are presented as growth curves. The optical density at $600 \mathrm{~nm}$ was measured at $0,24,48$, and $96 \mathrm{~h}$. The results are shown as means $\pm \mathrm{SE}$.

We analyzed the expression of the genes in vitro to check whether high temperatures had the same effect in vitro. The expression of the psyI gene was lower in bacteria grown at $31{ }^{\circ} \mathrm{C}$ than at $26^{\circ} \mathrm{C}$. The difference was more pronounced at $48 \mathrm{~h}$, and a similar behavior was observed for the fliC gene (Figure 8).
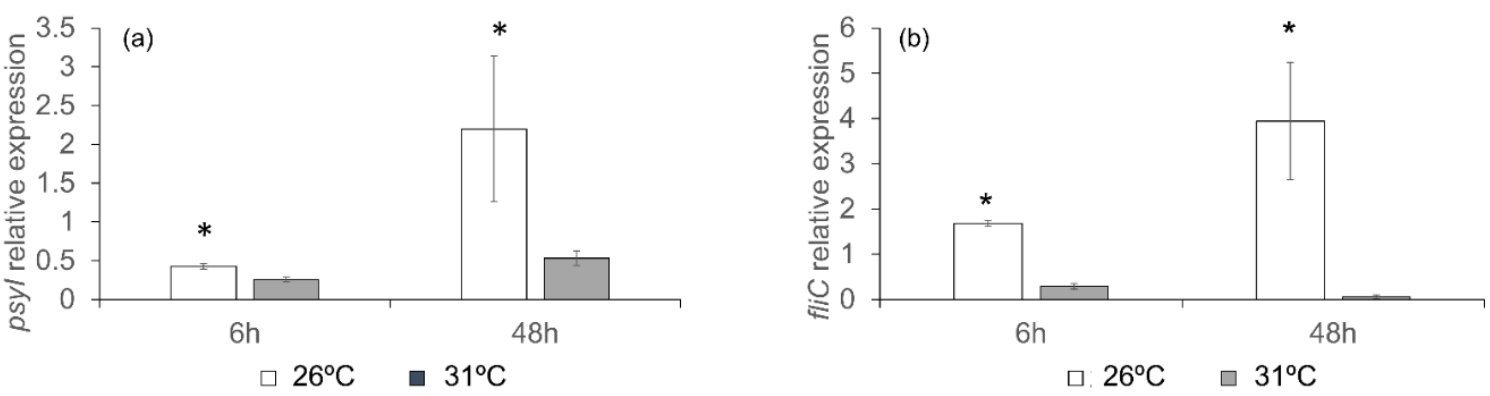

Figure 8. High temperatures reduce the expression of genes involved in QS establishment and in flagellin synthesis. The relative expression of psyI (a) and fliC (b) was determined by qRT-PCR in bacteria extracted from plants grown at $26{ }^{\circ} \mathrm{C}$ or $31^{\circ} \mathrm{C}$. The relative expression levels of $p s y I$ and fliC were normalized to those of $r e c A$. The results are shown as means $\pm \mathrm{SE}$ from three different experiments. An asterisk indicates statistically significant differences $(p<0.05)$.

Furthermore, there was a repression of genes involved in the synthesis of COR at $31{ }^{\circ} \mathrm{C}$, mainly at short time points, when compared to their expression at $26{ }^{\circ} \mathrm{C}$ (Figure $9 \mathrm{a}-\mathrm{C}$ ). These results indicate a possible negative role for the synthesis of this molecule in bacteria under these conditions. The expression of genes involved in the synthesis of the T3SS and avrPtoB effectors was also studied. An increase in the expression of $H r p L$ was observed at $6 \mathrm{~h}$ in bacteria grown at $31^{\circ} \mathrm{C}$ compared with bacteria grown at $26^{\circ} \mathrm{C}$ (Figure $6 \mathrm{~d}$ ). However, the difference was not significant. There were significant differences in the expression of hrp $A$ and avrPtoB genes (Figure 9e,f) at $6 \mathrm{~h}$, and in both cases, the expression was lower at $31^{\circ} \mathrm{C}$. The expression of $h r p A$ was 1.4 times lower in the bacteria grown at $31^{\circ} \mathrm{C}$ for short periods. However, the reduction in the expression of these genes was not as strong as that of the COR synthesis genes. 

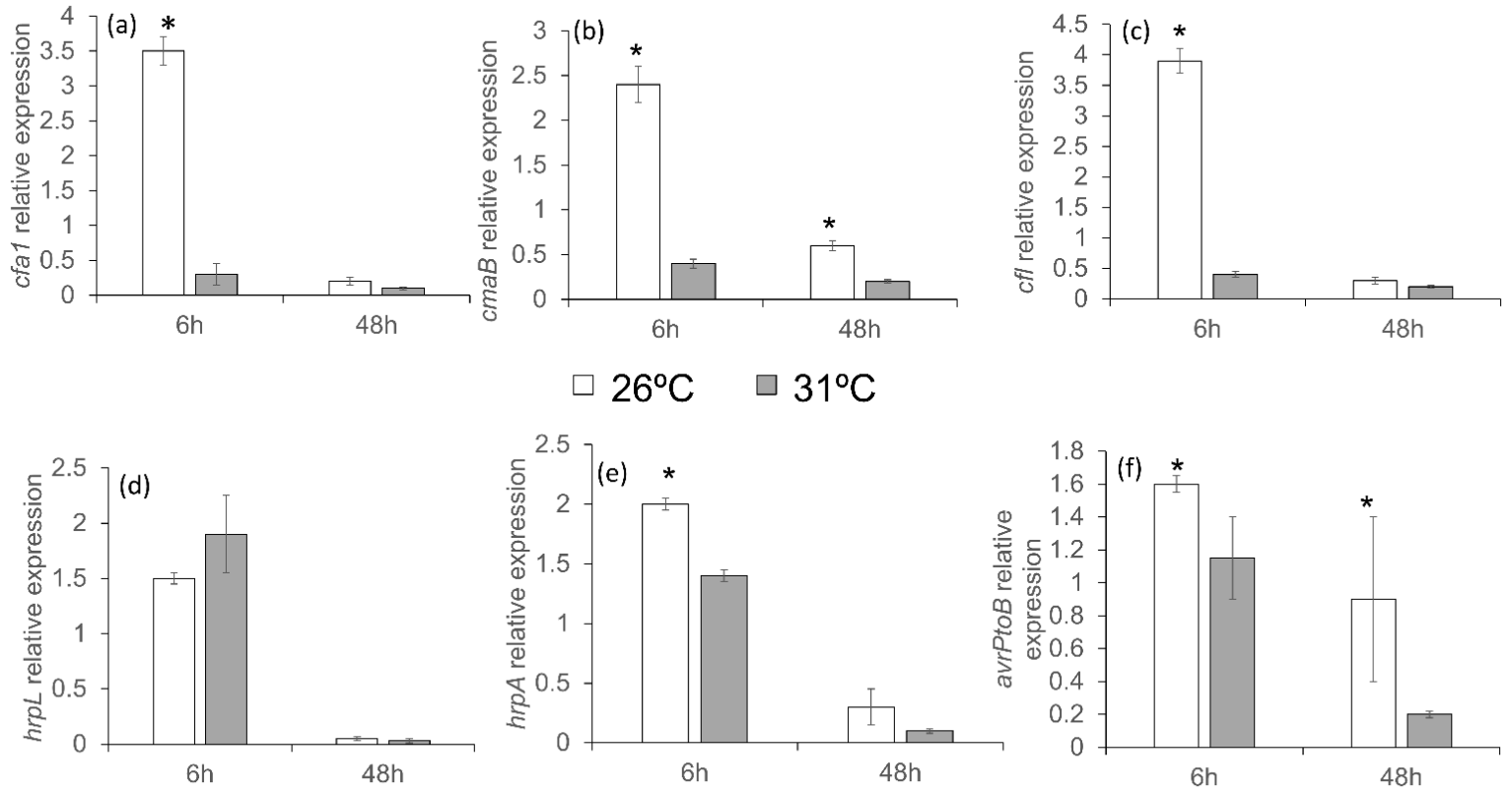

Figure 9. The effect of high temperatures on PstDC3000 virulence genes in vitro. The relative expressions of (a) $c f a 1$, (b) $c m a B$, (c) $c f l$, (d) HrpL, (e) HrpA, and (f) $\operatorname{avrPtoB}$ were determined. The internal reference gene was the $r e c A$ gene. The results represent the means $\pm \mathrm{SE}$ of three different experiments. An asterisk indicates statistically significant differences $(p<0.05)$.

\subsection{Response of Pseudomonas Mutants in Virulence Mechanisms to High Temperatures In Vitro}

We tested whether the synthesis of COR had a negative effect on the growth of PstDC3000 at $31^{\circ} \mathrm{C}$. Different mutants defective in COR synthesis $((\Delta c m a-c f a)$, T3SS synthesis and assembly $(\triangle h r p L)$, pillus formation $(\triangle h r p A)$, and effector synthesis $(\triangle a v r P t o-$ $\triangle a v r P t o B$ ) were grown in liquid $\mathrm{KB}$ medium at $26^{\circ} \mathrm{C}$ and $31^{\circ} \mathrm{C}$. No significant differences were observed in the growth of mutants compared to the wild type (WT) at optimal growth temperatures (Figure 10), while higher temperature led to decreased bacterial growth in all the tested strains. However, the mutant deficient in COR showed significantly higher growth at $31^{\circ} \mathrm{C}$ than the WT and other mutants. Differences in growth were observed in the $\Delta h r p L$ mutant, which was significantly reduced when compared to the WT.

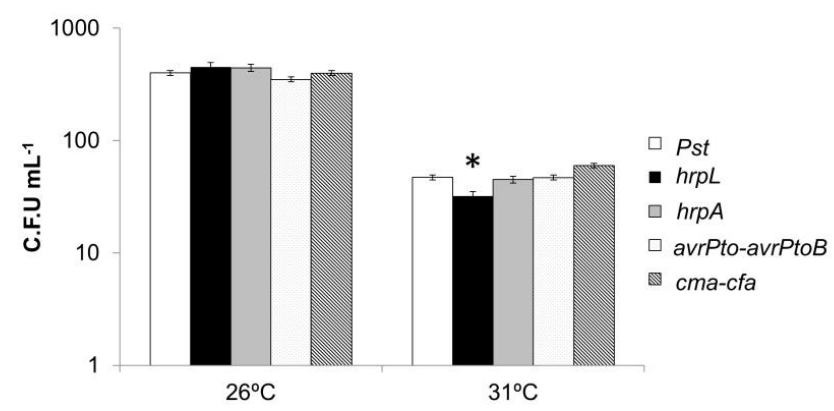

Figure 10. The effect of high temperatures on the growth of different PstDC3000 mutants in vitro. PstDC3000 mutants defective in COR synthesis $(\Delta c m a-c f a)$, in T3SS synthesis and assembly $(\Delta h r p L)$, in pillus formation $(\Delta h r p A)$, and in effector synthesis ( $\triangle$ avrPto- $\Delta$ avrPtoB) were grown in liquid $\mathrm{KB}$ medium at $26^{\circ} \mathrm{C}$ and $31^{\circ} \mathrm{C}$. The optical density at $600 \mathrm{~nm}$ was measured $24 \mathrm{hpi}$. The results represent the mean of three independent experiments with 8 replicates per mutant in each experiment. An asterisk indicates statistically significant differences $(p<0.05)$.

\subsection{Mild Heat Stress Affected PstDC3000 Mobility In Vitro}

On the basis of the results of flagellin synthesis, we tested whether PstDC3000 low mobility was due to the high temperatures. The swimming ability of the bacterium was 
tested at $26^{\circ} \mathrm{C}$ and $31^{\circ} \mathrm{C}$. This ability was almost completely reduced at high temperatures (Figure 11). The plates from the tests at high temperatures were incubated at $26{ }^{\circ} \mathrm{C}$ to check whether this effect was reversible. The bacteria regained their swimming ability to the same levels as those maintained at $26{ }^{\circ} \mathrm{C}$.

(a)

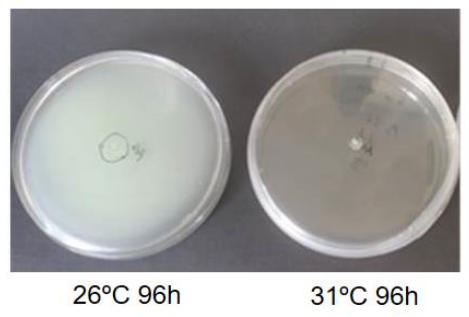

(b) 40

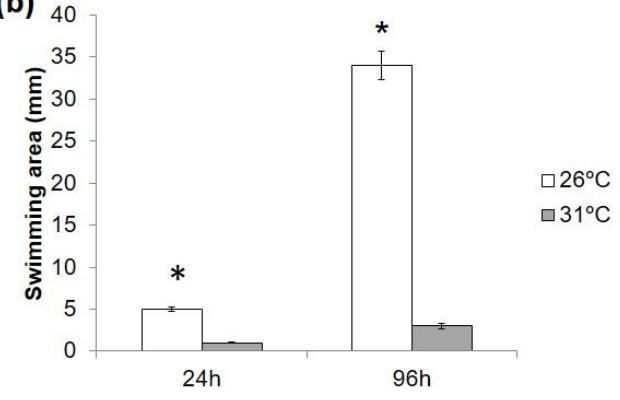

Figure 11. The effect of high temperatures on PstDC3000 motility in vitro. Swimming assays were performed as described above. (a) Bacteria culture in semi-solid medium after $96 \mathrm{~h}$ of incubation at $26{ }^{\circ} \mathrm{C}$ or $31{ }^{\circ} \mathrm{C}$ after. (b) Measurement of the diameter of the swimming area. The results represent the average of three independent experiments $\pm \mathrm{SE}$, and 5 plates per temperature were measured in each experiment. An asterisk indicates statistically significant differences $(p<0.05$, LSD test).

\section{Discussion}

The present study investigated the effect of environmental temperature increases on the plant-pathogen system. Tomato plants were tested to determine if they could acclimate to mild temperature stress, such as those predicted in climate change scenarios. Tomato plants cultivar Ailsa Graig were selected since it is a model tomato plant susceptible to Pst and also on the basis of a previous screening of different tomato varieties response to heat shock, where it gave an intermediate response compared to other varieties (unpublished data). The mechanism for changes in the development of disease from PstDC3000 in tomato plants resulting from moderate heat stress was determined by analyzing the defense mechanisms of the plant and the virulence mechanisms of the pathogen. Many recent studies have investigated biochemical and molecular plant strategies to survive a marked increase in external temperature. However, in the present study, we focused on plant response to a mild increase in the ambient temperature. Previous works showed that a mild increase in ambient temperature is not lethal for Arabidopsis plants, but it does cause significant changes in plant architecture and in the transition between the different developmental stages of its development. The morphological plasticity of plant adaptation to mild temperature increases is crop-dependent, as each crop responds with specific adaptations to achieve thermotolerance [6]. No symptoms of damage were observed during the two weeks in which the tomato plants were kept at $31^{\circ} \mathrm{C}$. However, several changes such as an increase in biomass and in chlorophyll content were observed in these plants. In addition to changes in anatomy, plants have developed changes in their metabolic profile to cope with external conditions that are less suitable. Several of these strategies are intricately linked to amino acid metabolism [38,39]. Plants accumulate amino acids and other low-molecularweight organic molecules called compatible osmolytes, which maintain cell turgor and are free-radical scavengers, or chemical chaperones [40-43]. This study demonstrated that mild-temperature stress conditions significantly increased the levels of several amino acids such as proline, serine, and valine. Proline is a multifunctional amino acid in plants, and its role in abiotic stress resistance has been extensively studied [44]. Alamri et al. [45] demonstrated that proline accumulation mediated by NO-derived signaling pathways increased the resistance of bean plants to heat stress. PAs are also known to be involved in acclimatization to different stresses [46]. In particular, putrescine has been shown to play an important role in resistance to salinity [47] and to cold and dehydration stress [48], but little is known about its role in thermotolerance. $\mathrm{T} 31^{\circ} \mathrm{C}$ tomato plants accumulated putrescine, which probably acts as a compatible osmolyte to overcome mild stress. Our results support 
the findings of Serrano et al. [49], who demonstrated that different metabolites, including putrescine, accumulate in higher amounts in thermoprimed Arabidopsis plants after heat stress exposure, thereby increasing their survival. These results showed that tomato plants grown under moderate heat stress exhibit an increase in metabolites that are likely used as thermotolerant metabolites. This will allow plants to adapt and survive the warmer environments predicted in climate change scenarios. We also evaluated the influence of an increase of $5{ }^{\circ} \mathrm{C}$ on the tomato-PstDC3000 pathosystem. The results show that tomato plants grown under mild-temperature stress conditions showed statistically significant reductions in disease symptoms and in the size of the bacterial population. We used two different approaches in the same pathosystem to investigate how moderate temperature stress affects disease in the tomato-PstDC3000 interaction. We investigated different mechanisms in tomato plants to defend against PstDC3000 infection. We also investigated the effect of high temperatures on the virulence factors in the bacteria. Analysis of the metabolic profile of the tomato-PstDC 3000 interaction in $\mathrm{T} 26^{\circ} \mathrm{C}$ sheds light on the signaling networks that act in this pathosystem under climate change scenarios. $\mathrm{T} 26^{\circ} \mathrm{C}$ tomato plants infected with PstDC3000 displayed a slight increase in ABA content, and a strong induction of SA-related responses, as demonstrated by the higher induction of $P R 1$ marker gene, as well as OPDA accumulation. $\mathrm{T} 31^{\circ} \mathrm{C}$ plants infected with PstDC3000 showed a decrease in PR1 expression and in SA and OPDA accumulation when compared with $\mathrm{T} 26{ }^{\circ} \mathrm{C}$-infected plants. We also observed a statistically significant accumulation of ABA and JA-Ile in $\mathrm{T} 31^{\circ} \mathrm{C}$ plants after PstDC3000 inoculation.

It is known that plants activate SA-related responses against biotrophic and hemibiotrophic pathogens such as PstDC3000, as well as JA-mediated responses in the regulation of resistance to diseases produced by necrotrophic pathogens [50]. Pst DC3000 synthesizes COR, a structural homolog of JA-Ile, and shares the CORONATINE INSENSITIVE1 (COI1)-JASMONATE ZIM domain (JAZ) as a coreceptor complex. Different studies have shown that in the presence of JA-Ile or COR, ubiquitin ligase complex E3 (SCFCOI1), ubiquitin JAZs for degradation in the proteasome, release transcription factors such as MYC2. This activates the signaling networks mediated by JA [51]. One of the strategies of Pst DC3000 is based on the synthesis of COR, whose ability to suppress the host defense is partially associated with antagonism of SA signaling through COI1 activation [31,52]. However, other studies have shown that jasmonates synergize with SA defenses $[38,53]$. Scalschi et al. [54] found a synergic induction of the SA and JA pathways, on the basis of OPDA accumulation in tomato plants infected with PstDC3000. These authors studied the behavior of SiOPR3 transgenic plants (plants whose Opr3 gene has been silenced, disrupting the JA synthesis pathway at the OPDA level) on PstDC3000 infection at normal temperatures. They demonstrated that the reduction in the severity of bacterial disease was accompanied by an enhancement of OPDA levels, as well as reduced levels of JA and JA-Ile [55]. This proves the importance of this oxylipin in the response of tomato plants to Pseudomonas and confirmed our results, as we observed a synergic activation of the SA and JA pathways with an increase in PR1 expression and OPDA accumulation in $\mathrm{T} 26^{\circ} \mathrm{C}$ plants. Activation of the JA pathway was also observed in $\mathrm{T} 31^{\circ} \mathrm{C}$ plants. However, this was not translated into an accumulation of OPDA, which is key in resistance against PstDC3000, but rather resulted in an accumulation of JA-Ile, which blocked the accumulation of SA and therefore SA-related defensive responses. However, this does not translate into further infection by bacteria.

ABA has been considered a negative regulator of disease resistance because it interferes with biotic stress signaling regulated by SA, JA, and ethylene [56]. Arabidopsis ABA-insensitive mutants abi2-1 and abi1-1 were more resistant to PstDC3000, whereas the ABA hypersensitive mutant (era1) was more susceptible [57,58]. In this study, we found a lower incidence of the disease produced by PstDC3000 at warm temperatures, accompanied by an altered tomato hormonal response based on the accumulation of ABA and JA-Ile. PstDC3000 inoculation induced the polyamine pathway in plants grown under both temperature conditions. However, T26 ${ }^{\circ} \mathrm{C}$ plants accumulated putrescine, whereas $\mathrm{T} 31^{\circ} \mathrm{C}$ 
plants displayed spermine accumulation 48 hpi. Fernández-Crespo et al. [59] demonstrated that putrescine treatment induces resistance to PstDC3000 in tomato plants, revealing the importance of putrescine in the resistance to biotic stress. Similarly, the elevation of endogenous spermine levels by transgenic overexpression of $S$-adenosylmethionine decarboxylase or spermine synthase induced resistance against $P$. syringae or Hyaloperonospora arabidopsidis in Arabidopsis plants [60]. The higher accumulation of spermine in T31 ${ }^{\circ} \mathrm{C}$-infected plants could help them cope with disease caused by PstDC3000 in warmer conditions. This study shows that tomato plants grown under mild heat stress conditions were able to detect the presence of the bacteria, but their defensive response differed from that observed in the control. In addition, the profile of both hormonal and PA accumulation did not correlate with a lower incidence of the disease severity observed in warmer conditions, as the mechanisms related to resistant phenotypes such as SA-mediated responses and OPDA or putrescine accumulation were not activated. Moreover, Huot et al. [61] studied the Arabidopsis-Pseudomonas triangular interaction, observing that elevated temperatures caused an increase in ABA content and a decrease in SA concentration. Consequently, these plants became more susceptible to the bacterial infection. In our study, we found similar hormonal responses in tomato plants infected with PstDC3000 and grown at increased temperatures. However, these changes were accompanied by a reduction in disease severity.

In the view of these results, we focused on the effect of mild temperature stress on the pathosystem, presenting a plausible hypothesis that moderate heat stress conditions directly affect the virulence machinery of the bacteria, triggering changes in the metabolic response profile observed between $\mathrm{T} 26^{\circ}$ and $\mathrm{T} 31^{\circ}$ infected tomato plants.

The potential negative impact on bacterial pathogenesis and growth resulting from a moderate increase in temperature was investigated by studying the behavior of $P$. syringae in plants under the two temperature conditions. The bacterial population was smaller in plants subjected to high temperatures. Pseudomonas conducts an epiphytic life cycle on the leaf surface [62] until, either through stomata or through wounds, it enters the mesophyll, where the endophytic life phase takes place. During this phase, the bacterium manages, through different virulence mechanisms, to manipulate and access the nutrients of the plant cell. The flagellum is the cellular component that helps bacteria move to better environments for survival. However, synthesis of the flagellum requires considerable energy expenditure [63]. This has been studied in bacteria under high temperatures stress both in vitro and in plants $[61,64]$. These studies demonstrated a clear inhibition of the expression of genes involved in the synthesis of flagellin. Our results support these studies, as repression of the fliC gene was observed in bacteria extracted from $\mathrm{T} 31^{\circ} \mathrm{C}$ plants. Analysis of the expression of genes involved in COR synthesis showed an inhibition in the bacteria extracted from $\mathrm{T} 31^{\circ} \mathrm{C}$ plants. It has previously been demonstrated that COR synthesis is affected by temperature, as in some pathovars, this toxin was preferentially produced in plants under low temperature conditions [65]. Despite this, the infective capacity of the bacteria was not completely reduced, as the infection ratio of $50 \%$ was most likely mediated by the maintenance of the T3SS. Surprisingly, HrpL expression was not affected by a temperature increase. Pathogenic bacteria use a variety of virulence factors that work in a "multifunctional, cooperative, and redundant" manner [66]. Recent studies indicate that the functions of the multifunctional COR toxin overlap with the T3SS function in PstDC3000. This helps the bacteria maintain their virulence when a virulence strategy fails because of a mutation or incompatibility with a given host [67]. In vitro assays were thus performed to determine if the bacteria could acclimatize to high temperatures if subjected to temperatures of $31^{\circ} \mathrm{C}$ for longer periods. No phenotypic changes or increases in the growth rate were observed in the colonies grown under these conditions, and growth rates were lower than in the cultures incubated at $26{ }^{\circ} \mathrm{C}$. These results indicate that even when the bacteria were subjected to high temperatures for longer periods, they could not acclimatize at temperatures above those optimal for their growth. The genes involved in the pathogenesis and growth of the bacteria were analyzed under in vitro conditions to determine the effect of high temperatures on PstDC3000. The results 
confirmed those obtained for the bacteria extracted from $\mathrm{T} 31^{\circ} \mathrm{C}$ plants, where inhibition of the fliC gene was observed in bacteria. The results of the swimming analysis confirmed that high temperatures affected the ability of PstDC3000 to move. Furthermore, as observed in plants, significant inhibition of genes related to the synthesis of COR was observed, while the genes related to T3SS were not affected. We thus speculate that virulence factors could interfere with the ability of bacteria to acclimatize to high temperature conditions. To test this hypothesis, we assessed the growth of several mutants defective in different virulence factors at high temperatures. Our results show that T3SS appears to be involved in the growth of the bacteria at high temperatures, as the $\Delta h r p L$ mutant growth was lower than that of the other mutants. These results support those described by other studies, which demonstrate that the flagellate and secretion systems are counter-regulated by temperature [68]. These studies, as well as most of the studies on T3SS, highlight the fact that it is mainly involved in bacterial virulence, which is achieved through effector delivery. The involvement of this system in cell-to-cell contact with eukaryotic hosts was also investigated, as the role of this system in the establishment of symbiotic reactions in nitrogen-fixing bacteria has been demonstrated by Marie et al. [69]. Moreover, this system seems to also play an important role in interactions between the plant cell and saprobic rhizosphere bacteria that establish beneficial relationships with root cells, such as growth-promoting bacteria [70]. Our results indicate that T3SS has a role in overcoming abiotic stresses, even in the absence of eukaryotic cells, as demonstrated by the results obtained in vitro. The role of this secretion system in the growth of bacteria has also been observed previously in vitro, where bacteria were grown in the presence of the resistance inducer hexanoic acid at a concentration that was deleterious for the bacteria [37]. However, considering the results obtained for the expression of the genes responsible for COR synthesis and the behavior of the mutants defective in its synthesis, we can conclude that COR absence facilitates the growth of the bacteria at high temperatures. It is clear that T3SS is necessary for the growth of bacteria at high temperatures, whereas the synthesis or presence of COR is detrimental to the ability of the bacteria to survive in unfavorable environments.

\section{Conclusions}

Infections were less severe than under control conditions, demonstrating that a $5{ }^{\circ} \mathrm{C}$ increase in temperature leads to changes in the tomato-PstDC3000 pathosystem. Tomato plants acclimated to mild heat stress and did not show any signs of damage. An increase in total biomass and chlorophyll content were observed. Moreover, tomato plants showed higher basal levels of metabolites such as proline and putrescine, which most likely act as compatible osmolytes, demonstrating their importance as key components of thermotolerance. When infected with PstDC3000, plants grown under warmer conditions increased ABA, JA-Ile, and spermine accumulation. An increase in temperature negatively affected the infective capacity of PstDC3000. The inhibition of the genes responsible for the establishment of the QS and the synthesis of flagellin and COR were observed in bacteria extracted from $\mathrm{T} 31^{\circ} \mathrm{C}$ plants. The analysis of the genes involved in the synthesis of T3SS points to the important role of HrpL in bacterial growth under these conditions. Changes in the virulence mechanisms of PstDC3000 under high-temperature conditions may explain the lower infection rates observed in $\mathrm{T} 31^{\circ} \mathrm{C}$ plants, as the resistance mechanisms involved in the defense against this bacterium, such as SA, putrescine, or OPDA accumulation, were not observed in these plants. However, the presence of other metabolites or mechanisms involved in reducing the severity of the disease in such scenarios cannot be discounted. Our results shed light on the mechanisms underlying the effect of high temperatures on the tomato-PstDC3000 pathosystem. A complete understanding of how environmental factors can affect disease development is a challenge for researchers. It is critical to develop crops resistant to biotic stresses that can also cope with the unfavorable conditions related to climate change. 


\begin{abstract}
Author Contributions: Formal analysis and investigation: L.S., E.F.-C., M.P.-M., G.C., A.I.G.-H., E.L. and B.V. Contributing to writing the manuscript: L.S., E.F.-C., G.C., B.V. and P.G.-A. Project administration: P.G.-A. and B.V. Funding acquisition: P.G.-A. and B.V. Visualization and supervision: B.V. and P.G.-A. All authors have read and agreed to the published version of the manuscript.

Funding: This research has been funded by the FEDER/Ministry of Science Innovation and Universities- Spanish State Research Agency/_Project AGL2017-85987-C3-1-R. and by the Pla de Promoció de la Investigació of Universitat Jaume I (UJI-B2017-30 and UJI-A2019-19) E.L. is the holder of a "Juan de la Cierva-Incorporación" fellowship from MINECO (IJCI-2016-29744), A.I.G.-H. is the holder of predoctoral grant UJI-PREDOC /2016/27, and E.F.-C. is the holder of a posdoctoral grant UJI-POSDOC-A/2017/20.
\end{abstract}

Institutional Review Board Statement: Not applicable.

Informed Consent Statement: Not applicable.

Data Availability Statement: The data that support the findings of this study are available from the corresponding author upon reasonable request.

Acknowledgments: We thank Serveis Centrals d'Intrumentació Científica (SCIC) from Universitat Jaume I (UJI, Castellón, Spain).

Conflicts of Interest: The authors declare no conflict of interest.

\title{
References
}

1. Bita, C.E.; Gerats, T. Plant tolerance to high temperature in a changing environment: Scientific fundamentals and production of heat stress-tolerant crops. Front. Plant Sci. 2013, 4, 273. [CrossRef] [PubMed]

2. Zhao, C.; Liu, B.; Piao, S.; Wang, X.; Lobell, D.B.; Huang, Y.; Huang, M.T.; Yao, Y.T.; Bassu, S.; Ciais, P.; et al. Temperature increase reduces global yields of major crops in four independent estimates. Proc. Natl. Acad. Sci. USA 2017, 114, 9326-9331. [CrossRef] [PubMed]

3. Field, C.B.; Barros, V.R.; Dokken, D.J.; Mach, K.J.; Mastrandrea, M.D.; Bilir, T.E. Cambio Climático 2014 Impactos, Adaptación y Vulnerabilidad; IPCC: Geneva, Switzerland, 2014.

4. Guy, C. Molecular responses of plants to cold shock and cold acclimation. J. Mol. Microbiol. Biotechnol. 1999, 1, 231-242. [PubMed]

5. Mazzeo, M.F.; Cacace, G.; Iovieno, P.; Massarelli, I.; Grillo, S.; Siciliano, R.A. Response mechanisms induced by exposure to high temperature in anthers from thermo-tolerant and thermo-sensitive tomato plants: A proteomic perspective. PLoS ONE 2018, 13, e0201027. [CrossRef]

6. Casal, J.J.; Balasubramanian, S. Thermomorphogenesis. Annu. Rev. Plant Biol. 2019, 70, 321-346. [CrossRef]

7. Quint, M.; Delker, C.; Franklin, K.A.; Wigge, P.; Halliday, K.; Van Zanten, M. Molecular and genetic control of plant thermomorphogenesis. Nat. Plants 2016, 2, 15190. [CrossRef]

8. Baniwal, S.K.; Chan, K.Y.; Scharf, K.-D.; Nover, L. Role of Heat Stress Transcription Factor HsfA5 as Specific Repressor of HsfA4 J. Biol. Chem. 2007, 282, 3605-3613. [CrossRef]

9. Kotak, S.; Vierling, E.; Bäumlein, H.; von Koskull-Döring, P. A Novel Transcriptional Cascade Regulating Expression of Heat Stress Proteins during Seed Development of Arabidopsis. Plant Cell 2007, 19, 182-195. [CrossRef]

10. Nievola, C.C.; Carvalho, C.P.; Carvalho, V.; Rodrigues, E. Rapid responses of plants to temperature changes. Temperature 2017, 4, 371-405. [CrossRef]

11. Iba, K. Acclimative response to temperature stress in higher plants: Approaches of Gene Engineering for Temperature Tolerance. Annu. Rev. Plant Biol. 2002, 53, 225-245. [CrossRef]

12. Wahid, A.; Gelani, S.; Ashraf, M.; Foolad, M.R. Heat tolerance in plants: An overview. Environ. Exp. Bot. 2007, 61, 199-223. [CrossRef]

13. Sung, D.-Y.; Kaplan, F.; Lee, K.-J.; Guy, C.L. Acquired tolerance to temperature extremes. Trends Plant Sci. 2003, 8, 179-187. [CrossRef]

14. Mirzaei, M.; Pascovici, D.; Atwell, B.J.; Haynes, P.A. Differential regulation of aquaporins, small GTPases and V-ATPases proteins in rice leaves subjected to drought stress and recovery. Proteomics 2012, 12, 864-877. [CrossRef] [PubMed]

15. Anwar Hossain, M.; Hoque, M.A.; Burritt, D.J.; Fujita, M. Proline Protects Plants against Abiotic Oxidative Stress: Biochemical and Molecular Mechanisms. In Oxidative Damage to Plants: Antioxidant Networks and Signaling; Elsevier: Amsterdam, The Netherlands, 2014; pp. 477-522.

16. Francl, L.J. The Disease Triangle: A Plant Pathological Paradigm Revisited. Plant Health Instr. 2001, 10. [CrossRef]

17. Spoel, S.H.; Dong, X. How do plants achieve immunity? Defence without specialized immune cells. Nat. Rev. Immunol. 2012, 12, 89-100. [CrossRef]

18. Zhou, J.M.; Zhang, Y. Plant Immunity: Danger Perception and Signaling. Cell 2020, 181, 978-989. [CrossRef]

19. Beckers, G.J.M.; Spoel, S.H. Fine-Tuning Plant Defence Signalling: Salicylate versus Jasmonate. Plant Biol. 2006, 8, 1-10. [CrossRef] 
20. Pieterse, C.M.J.; Van der Does, D.; Zamioudis, C.; Leon-Reyes, A.; Van Wees, S.C.M. Hormonal Modulation of Plant Immunity. Annu. Rev. Cell Dev. Biol. 2012, 28, 489-521. [CrossRef]

21. Bürger, M.; Chory, J. Stressed Out About Hormones: How Plants Orchestrate Immunity. Cell Host Microbe 2019, 14, 163-172. [CrossRef]

22. Takahashi, T.; Kakehi, J.-I. Polyamines: Ubiquitous polycations with unique roles in growth and stress responses. Ann. Bot. 2010, 105, 1-6. [CrossRef]

23. Zeir, J. New insights into the regulation of plant immunity by amino acid metabolic pathways. Plant Cell Environ. 2013, 36, 2085-2103. [CrossRef] [PubMed]

24. Velásquez, A.C.; Castroverde, C.D.M.; He, S.Y. Plant-Pathogen Warfare under Changing Climate Conditions. Curr. Biol. 2018, 28, R619-R634. [CrossRef] [PubMed]

25. Katagiri, F.; Thilmony, R.; He, S.Y. The Arabidopsis thaliana-Pseudomonas syringae Interaction. Arab. Book 2002, 1, e0039. [CrossRef] [PubMed]

26. Buell, C.R.; Joardar, V.; Lindeberg, M.; Selengut, J.; Paulsen, I.T.; Gwinn, M.L.; Dodson, R.J.; DeBoy, R.T.; Durkin, A.S.; Kolonay, J.F.; et al. The complete genome sequence of the Arabidopsis and tomato pathogen Pseudomonas syringae pv. tomato DC3000. Proc. Natl. Acad. Sci. USA 2003, 100, 10181-10186. [CrossRef]

27. Melotto, M.; Underwood, W.; He, S.Y. Role of Stomata in Plant Innate Immunity and Foliar Bacterial Diseases. Annu. Rev. Phytopathol. 2008, 46, 101-122. [CrossRef]

28. Chatterjee, A.; Cui, Y.; Hasegawa, H.; Chatterjee, A.K. PsrA, the Pseudomonas Sigma Regulator, Controls Regulators of Epiphytic Fitness, Quorum-Sensing Signals, and Plant Interactions in Pseudomonas syringae pv. tomato Strain DC3000. Appl. Environ. Microbiol. 2007, 73, 3684-3694. [CrossRef]

29. He, S.Y.; Nomura, K.; Whittam, T.S. Type III protein secretion mechanism in mammalian and plant pathogens. Biochim. Et Biophys. Acta Mol. Cell Res. 2004, 1694, 181-206. [CrossRef]

30. Coburn, B.; Sekirov, I.; Finlay, B.B. Type III Secretion Systems and Disease. Clin. Microbiol. Rev. 2007, 20, 535-549. [CrossRef]

31. Cui, H.; Xiang, T.; Zhou, J.-M. Plant immunity: A lesson from pathogenic bacterial effector proteins. Cell. Microbiol. 2009, 11, 1453-1461. [CrossRef]

32. Xin, X.-F.; Kvitko, B.; He, S.Y. Pseudomonas syringae: What it takes to be a pathogen. Nat. Rev. Genet. 2018, 16, 316-328. [CrossRef]

33. King, E.O.; Ward, M.K.; Raney, D.E. Two simple media for the demonstration of pyocyanin and fluorescin. J. Lab. Clin. Med. 1954, 44, 301-307. [PubMed]

34. Scalschi, L.; Llorens, E.; González-Hernández, A.I.; Valcárcel, M.; Gamir, J.; Agustín, P.G.; Vicedo, B.; Camañes, G. 1Methyltryptophan Modifies Apoplast Content in Tomato Plants Improving Resistance Against Pseudomonas syringae. Front. Microbiol. 2018, 9, 2056. [CrossRef] [PubMed]

35. Sánchez-López, J.; Camañes, G.; Flors, V.; Vicent, C.; Pastor, V.; Vicedo, B.; Cerezo, M.; García-Agustín, P. Underivatized polyamine analysis in plant samples by ion pair LC coupled with electrospray tandem mass spectrometry. Plant Physiol. Biochem. 2009, 47, 592-598. [CrossRef] [PubMed]

36. Yu, X.; Lund, S.P.; Scott, R.A.; Greenwald, J.W.; Records, A.H.; Nettleton, D.; Lindow, S.E.; Gross, D.C.; Beattie, G.A. Transcriptional responses of Pseudomonas syringae to growth in epiphytic versus apoplastic leaf sites. Proc. Natl. Acad. Sci. USA 2013, 110, E425-E434. [CrossRef] [PubMed]

37. Scalschi, L.; Camañes, G.; Llorens, E.; Fernández-Crespo, E.; López, M.M.; Agustín, P.G.; Vicedo, B. Resistance Inducers Modulate Pseudomonas syringae pv. Tomato Strain DC3000 Response in Tomato Plants. PLoS ONE 2014, 9, e106429. [CrossRef] [PubMed]

38. Rao, K.V.M.; Raghavendra, A.S.; Reddy, K.J. Physiology and Molecular Biology of Stress Tolerance in Plants; Springer: Dordrecht, The Netherlands, 2006.

39. Hildebrandt, T.M. Synthesis versus degradation: Directions of amino acid metabolism during Arabidopsis abiotic stress response. Plant Mol. Biol. 2018, 98, 121-135. [CrossRef]

40. Hare, P.D.; Cress, W.A.; Van Staden, J. Dissecting the roles of osmolyte accumulation during stress. Plant Cell Environ. 1998, 21, 535-553. [CrossRef]

41. McNeil, S.D.; Nuccio, M.L.; Hanson, A.D. Betaines and Related Osmoprotectants. Targets for Metabolic Engineering of Stress Resistance. Plant Physiol. 1999, 120, 945-949. [CrossRef]

42. Diamant, S.; Eliahu, N.; Rosenthal, D.; Goloubinoff, P. Chemical Chaperones Regulate Molecular Chaperones in Vitro and in Cells under Combined Salt and Heat Stresses. J. Biol. Chem. 2001, 276, 39586-39591. [CrossRef]

43. Bokszczanin, K.L.; Solanaceae Pollen Thermotolerance Initial Training Network (SPOT-ITN) Consortium; Fragkostefanakis, S. Perspectives on deciphering mechanisms underlying plant heat stress response and thermotolerance. Front. Plant Sci. $2013,4,315$. [CrossRef]

44. Hayat, S.; Hayat, Q.; Alyemeni, M.N.; Wani, A.S.; Pichtel, J.; Ahmad, A. Role of proline under changing environments: A review. Plant Signal Behav. 2012, 7, 1456-1466. [CrossRef] [PubMed]

45. Alamri, S.; Siddiqui, M.H.; Al-Khaishany, M.Y.; Khan, M.N.; Ali, H.M.; Alakeel, K.A. Nitric oxide-mediated cross-talk of proline and heat shock proteins induce thermotolerance in Vicia faba L. Environ. Exp. Bot. 2019, 161, 290-302. [CrossRef]

46. Tiburcio, A.F.; Altabella, T.; Bitrian, M.; Alcázar, R. The roles of polyamines during the lifespan of plants: From development to stress. Planta 2014, 240, 1-18. [CrossRef] [PubMed] 
47. Fernández-Crespo, E.; Camañes, G.; García-Agustín, P. Ammonium enhances resistance to salinity stress in citrus plants. J. Plant Physiol. 2012, 169, 1183-1191. [CrossRef]

48. Alet, A.I.; Sanchez, D.H.; Cuevas, J.C.; Del Valle, S.; Altabella, T.; Tiburcio, A.F.; Marco, F.; Ferrando, A.; Espasandín, F.D.; González, M.E.; et al. Putrescine accumulation in Arabidopsis thaliana transgenic lines enhances tolerance to dehydration and freezing stress. Plant Signal. Behav. 2011, 6, 278-286. [CrossRef]

49. Serrano, N.; Ling, Y.; Bahieldin, A.; Mahfouz, M.M. Thermopriming reprograms metabolic homeostasis to confer heat tolerance. Sci. Rep. 2019, 9, 181. [CrossRef]

50. Fu, Z.Q.; Yan, S.; Saleh, A.; Wang, W.; Ruble, J.; Oka, N.; Mohan, R.; Spoel, S.; Tada, Y.; Zheng, N.; et al. NPR3 and NPR4 are receptors for the immune signal salicylic acid in plants. Nature 2012, 486, 228-232. [CrossRef]

51. Fonseca, S.; Chini, A.; Hamberg, M.; Adie, B.; Porzel, A.; Kramell, R.; Miersch, O.; Wasternack, C.; Solano, R. (+)-7-iso-JasmonoylL-isoleucine is the endogenous bioactive jasmonate. Nat. Chem. Biol. 2009, 5, 344-350. [CrossRef]

52. Kloek, A.P.; Verbsky, M.L.; Sharma, S.B.; Schoelz, J.E.; Vogel, J.; Klessig, D.F.; Kunkel, B.N. Resistance to Pseudomonas syringae conferred by an Arabidopsis thaliana coronatine-insensitive (coi1) mutation occurs through two distinct mechanisms. Plant J. 2001, 26, 509-522. [CrossRef]

53. Jin, H.; Zhu, Z. Dark, Light, and Temperature: Key Players in Plant Morphogenesis. Plant Physiol. 2019, 180, 1793-1802. [CrossRef]

54. Scalschi, L.; Vicedo, B.; Camanes, G.; Fernandez-Crespo, E.; Lapeña, L.; González-Bosch, C.; García-Agustín, P. Hexanoic acid is a resistance inducer that protects tomato plants against Pseudomonas syringae by priming the jasmonic acid and salicylic acid pathways. Mol Plant Pathol. 2013, 14, 342-355. [CrossRef] [PubMed]

55. Scalschi, L.; Llorens, E.; García-Agustín, P.; Vicedo, B. Role of Jasmonic Acid Pathway in Tomato Plant-Pseudomonas syringae Interaction. Plants 2020, 9, 136. [CrossRef] [PubMed]

56. Mauch-Mani, B.; Mauch, F. The role of abscisic acid in plant-pathogen interactions. Curr. Opin. Plant Biol. 2005, 8, 409-414. [CrossRef] [PubMed]

57. De Torres-Zabala, M.; Truman, W.; Bennett, M.H.; Lafforgue, G.; Mansfield, J.W.; Rodriguez Egea, P.; Bögre, L.; Grant, M Pseudomonas syringae pv. tomato hijacks the Arabidopsis abscisic acid signalling pathway to cause disease. EMBO J. 2007, 26, 1434-1443. [CrossRef]

58. Goritschnig, S.; Weihmann, T.; Zhang, Y.; Fobert, P.; McCourt, P.; Li, X. A Novel Role for Protein Farnesylation in Plant Innate Immunity. Plant Physiol. 2008, 148, 348-357. [CrossRef]

59. Fernández-Crespo, E.; Scalschi, L.; Llorens, E.; García-Agustín, P.; Camañes, G. $\mathrm{NH}_{4}{ }^{+}$protects tomato plants against Pseudomonas syringae by activation of systemic acquired acclimation. J. Exp. Bot. 2015, 66, 6777-6790. [CrossRef]

60. Marco, F.; Busó, E.; Carrasco, P. Overexpression of SAMDC1 gene in Arabidopsis thaliana increases expression of defense-related genes as well as resistance to Pseudomonas syringae and Hyaloperonospora arabidopsidis. Front. Plant Sci. 2014, 5, 115. [CrossRef]

61. Huot, B.; Castroverde, C.D.M.; Velásquez, A.C.; Hubbard, E.; Pulman, J.A.; Yao, J.; Childs, K.L.; Tsuda, K.; Montgomery, B.L.; He, S.Y. Dual impact of elevated temperature on plant defence and bacterial virulence in Arabidopsis. Nat. Commun. 2017, 8, 1808-1812. [CrossRef]

62. Hirano, S.S.; Upper, C.D. Bacteria in the Leaf Ecosystem with Emphasis on Pseudomonas syringae-A Pathogen, Ice Nucleus, and Epiphyte. Microbiol. Mol. Biol. Rev. 2000, 64, 624-653. [CrossRef]

63. Zhao, K.; Liu, M.; Burgess, R.R. Adaptation in bacterial flagellar and motility systems: From regulon members to 'foraging'-like behavior in E. coli. Nucleic Acids Res. 2007, 35, 4441-4452. [CrossRef]

64. Hockett, K.L.; Burch, A.Y.; Lindow, S.E. Thermo-Regulation of Genes Mediating Motility and Plant Interactions in Pseudomonas syringae. PLoS ONE 2013, 8, e59850. [CrossRef] [PubMed]

65. Weingart, H.; Stubner, S.; Schenk, A.; Ullrich, M.S. Impact of Temperature on In Planta Expression of Genes Involved in Synthesis of the Pseudomonas syringae Phytotoxin Coronatine. Mol. Plant-Microbe Interact. 2004, 17, 1095-1102. [CrossRef] [PubMed]

66. Dean, P.; Kenny, B. The effector repertoire of enteropathogenic E. coli: Ganging up on the host cell. Curr. Opin. Microbiol. 2009, 12, 101-109. [CrossRef] [PubMed]

67. Geng, X.; Jin, L.; Shimada, M.; Kim, M.G.; Mackey, D. The phytotoxin coronatine is a multifunctional component of the virulence armament of Pseudomonas syringae. Planta 2014, 240, 1149-1165. [CrossRef]

68. Diepold, A.; Armitage, J.P. Type III secretion systems: The bacterial flagellum and the injectisome. Philos. Trans. R. Soc. B Biol. Sci. 2015, 370, 20150020. [CrossRef]

69. Marie, C.; Broughton, W.J.; Deakin, W.J. Rhizobium type III secretion systems: Legume charmers or alarmers? Curr. Opin. Plant Biol. 2001, 4, 336-342. [CrossRef]

70. Mazurier, S.; Lemunier, M.; Siblot, S.; Mougel, C.; Lemanceau, P. Distribution and diversity of type III secretion system-like genes in saprophytic and phytopathogenic fluorescent pseudomonads. FEMS Microbiol. Ecol. 2004, 49, 455-467. [CrossRef] 